\title{
UNIVERSITY RESEARCH AND KNOWLEDGE TRANSFER: A Dynamic View of Ambidexterity in British Universities
}

\author{
Abhijit Sengupta \\ Corresponding Author. University of Essex, United Kingdom. \\ Email: asengua@essex.ac.uk
}

Amit S Ray

Centre for International Trade and Development, School of International Studies, Jawaharlal Nehru

University, New Delhi 110067, India

Email: asr0504@mail.jnu.ac.in

\begin{abstract}
This paper examines the dynamic interlinkages between the two pillars of ambidexterity in universities, research and knowledge transfer. We propose a theoretical model linking these two pillars at the organisational level. The model is tested using the longitudinal HE-BCI survey data juxtaposed against two consecutive rounds of research evaluation in the UK higher education sector. Results indicate that a university's past performance along the research pillar strengthens the knowledge transfer pillar over time, through both commercialisation and academic engagement channels. This positive impact is negatively moderated by the university's size and reputation, in the sense that in larger or more reputed universities, the marginal impact of research on knowledge transfer declines significantly. Additionally, we find that knowledge transfer reinforces the research pillar through positive mediation between past and future research, but only through academic engagement channels. The results also indicate that contract research routes provide the maximum benefit for most universities in enhancing their ambidexterity framework, both in the short and the long run. For the relatively more reputed universities, it is the collaboration route which provides the maximum benefit. Interestingly, no such reinforcement could be detected in the case of the research commercialisation channels.
\end{abstract}

\section{Keywords}

Knowledge transfer, Academic engagement, Commercialisation, HE-BCI data, University-industry links, Ambidexterity 


\section{INTRODUCTION}

Universities have traditionally been conceptualised as centres of learning and creation of new knowledge, driven primarily by the traditional Mertonian norms of fundamental research and education (Dasgupta and David, 1994). However, over the last few decades, this traditional viewpoint has undergone a slow but sure change, with centres of higher education now being increasingly viewed as a key player in the entrepreneurial and innovation ecosystem within the broader economy. One of the key reasons behind this is the paradigm shift in the economic, social and technological climate that universities operate within, the challenges they face and consequent change in focus (Siegel and Wright, 2015). Recently, universities in many countries have faced financial constraints (Bhattacharya, 2006), which have motivated them to explore alternative models of funding research - most notably through increased interactions with industry (Curi et.al., 2012; Deiaco et.all, 2009). Individual researchers have had to adapt in response to the organizational changes as well, and to increasing emphasis on impact in research funding and career progression (Hughes and Kitson, 2012).

The shifting paradigm in the environment has led universities to adapt both structurally and strategically. Strategically, universities are increasingly focussing on their "third mission" activities, in parallel to research and education. This refers to all activities involving "generation, use, application and exploitation of knowledge and other university capabilities outside the academic environment" (Molas-Gallart et.al., 2002). While this includes a number of parallel strands of activities, "knowledge transfer" to the private and public sectors account for a significant proportion of income generation for the higher education sector (Rosli and Rossi, 2016). Consequently, the structural response has been led through the creation of specialised organisational subunits dedicated to managing these knowledge transfer activities with industry and other practitioners. Referred to as Knowledge Transfer Offices or KTOs, these act as an interface between researchers and research users by establishing procedures and infrastructure in place for taking research to its users (Bercovitz et.al., 2001). These shifts in the higher education sector are increasingly being examined in the light of what has been referred to as "ambidexterity" in the organisational literature (Ambos et.al., 2008; Chang et.al., 2009; Chang et.al., 2016).

Ambidexterity as a concept has its antecedents in the traditional organisational literature (Duncan, 1976; Tushman and O'Reilly, 1996; Tushman and O'Reilly, 1997). In general, ambidexterity in an innovative organisation refers to its ability to develop structures and processes, which allows them to carry our both "exploitation" and "exploration" activities sequentially or simultaneously - either at an individual or at an organisational level (Raisch et.al., 2009). In the context of a university, ambidexterity refers to its ability to carry out parallel activities outside its traditional one centred around research and education, typically those lying in the realm of commerce and engagement with practitioners (Ambos et.al., 2008). In essence, it conceptualises universities to be standing on two pillars - one which provides the foundation for its traditional role as a centre of education and research (Dasgupta and David, 1994), 
and the other provides the foundation for its third mission activities encompassing knowledge transfer and other forms of engagement with non-academic stakeholders (Etzkowitz, 2003). The primary purpose of this paper is to explore the relationship between these two pillars at the organisational level, and uncover the mechanisms through which the two interact and possibly feedback on each other. We explore the consequences of these interactions on a university's evolution using an inter-temporal model and explore the implications for universities and the higher education sector.

It is important to uncover how the practice of ambidexterity impacts a university's core performance in its key missions, especially given the recent shifts in the higher education sector (Martin, 2012). Facing increased competition and institutional pressures, knowledge transfer is no longer the preserve of a few universities or a handful of researchers, but is becoming common across the board (SanchezBarrioluengo et.al., 2014). Universities are increasingly being viewed as "entrepreneurial", who can use the knowledge created internally to pursue commercial objectives based on sound financial considerations (Lockett et.al., 2015; Siegel and Wright, 2015). In fact, such dual arrangements in the form of KTOs and associated institutional processes have become ubiquitous (Perkmann et.al., 2013). While the effect of being an ambidextrous organisation has been seen to positively impact knowledge transfer (Ambos et.al., 2008; Chang et.al., 2016), the implications of ambidexterity on research and knowledge transfer activities, and more specifically on the dynamic interlinkages between the two are yet unexplored.

Universities have almost universally incorporated ambidexterity within their strategic and structural framework, but still remain extremely heterogeneous in actually reaping its benefits (Geuna and Nesta, 2006; Hewitt-Dundas, 2012; Kitagawa et.al., 2016; Sanchez-Barrioluengo, 2014). Previous research finds a degree of correlation in the research performance and performance along various routes of knowledge transfer (Hewitt-Dundas, 2012; O'Shea et.al., 2005; Valdivia, 2013), although the mechanisms behind it are unclear at the level of an organisation. This paper attempts to uncover these mechanisms by addressing the following questions. First, how do the pillars of ambidexterity interact with each other over time? Specifically, what are the dynamic inter-linkages and the nature of feedback between activities which underpin ambidexterity in a university? Secondly, is there any evidence of path dependence in these pillars? In particular, is the connection between these pillars dependent on university level factors, such as size or reputation?

The tensions between the two pillars of ambidexterity are clear conceptually - research at its heart is a public good (Dasgupta and David, 1994), whereas engagement with non-academic stakeholders involves private ownership of knowledge (Etzkowitz et.al., 2000). In practice, this leads to conflicts in terms of the nature of research - blue sky versus applied (D'Este and Perkmann, 2011) - and in terms of time frames for disclosure - academic researchers wishing to disseminate research freely while practitioners may wish for secrecy and control (Dasgupta and David, 1994; Chang et.al., 2016). These 
tensions become apparent, not just for an individual researcher, but also for departments and very crucially, for the university itself - given the finite availability of resources and capabilities.

To resolve this tension, it is important to uncover the underlying mechanisms of how new research links into new knowledge transfer opportunities, and vice versa. Ambos et.al. (2008) show that organisational ambidexterity leads to greater likelihood of knowledge transfer overall. In a recent study by Chang et.al. (2016), the authors link individual and departmental ambidexterity to commercial performance. Our contribution lies in understanding the nature of the link between research and knowledge transfer at the organisational level. In doing so, we extend the literature in a number of directions. First of all, we examine the intertemporal nature of this relationship, which has been largely ignored in the literature. Second, we attempt to link this relationship to organisational characteristics to uncover the nature of path dependence (if any) in a university's ambidexterity framework. Finally, we focus on this relationship at the organisational level, without limiting ourselves to specific disciplines, individual capabilities or specific channels of interaction.

This paper makes a theoretical contribution towards understanding these mechanisms by establishing directional links between research and knowledge transfer, accounting for the fact that these activities may happen at different points in time. Empirical support for the theoretical model is made using data from the UK, which is suitable for two primary reasons. Universities in the UK have not been subjected to high profile Bayh-Dole type of legislations, as seen in the US and many other countries, and which has resulted in a more organic evolution of the sector. ${ }^{1}$ Additionally, UK is one of the few countries where publicly available university level data sets are available going back several years, enabling researchers to examine these organisations, their operations and evolution in detail.

The rest of the paper is organized as follows. In the following section, we discuss the existing literature on the topic and identify the gaps therein to motivate our study. Here we also present the hypotheses on which our study is based along and the theoretical model which we attempt to establish. In Section 3, we present the overall empirical design of our study, discuss the data sets used and the methodology employed. This is followed by a discussion of the results in Section 4. Finally, Section 5 concludes with a discussion and policy implications.

\footnotetext{
1 The United States was the pioneer in creating an institutional framework to facilitate university-industry knowledge transfer through the enactment of the Bayh-Dole Act of 1980 that focused exclusively on a formal intellectual property (IP) driven channel. While there has been a rise in university patenting in the U.S. following the legislation (Mowery and Sampat, 2005), whether this could be attributed to the creation of the Act itself have been hotly debated (Henderson et.al., 1998; Mowery et. al., 2001; Thursby and Thursby, 2002).
} 


\section{BACKGROUND AND THEORY DEVELOPMENT}

\subsection{Twin pillars of ambidexterity}

As a concept, ambidexterity refers to an organisation's ability to carry out its core functions while at the same time build capacity to carry out tasks outside its core capabilities in order to enhance performance, and has been widely applied in the organisational literature (Cao et.al., 2009; Raisch et.al., 2009; Tushman and O'Reilly, 1997). Ambidexterity in a university context, implies that it should be able to build capabilities and incorporate processes which encourage and enhance its third mission activities (knowledge exploitation), while simultaneously maintaining its focus on fundamental research (knowledge creation). It is increasingly being seen as a key factor for success in knowledge transfer for individual researchers (Boehm and Hogan, 2014; Markides, 2007), for departments (Chang et.al., 2016), as well as for the university (Ambos et.al., 2008).

Knowledge transfer is one of the key processes through which universities carry out its third mission activities (Rosli and Rossi, 2015). Knowledge transfer is not a single homogenous concept, but can occur through a number of routes, both formal and informal. The Bayh-Dole Act of 1980 in the US was a pioneering step in formalising knowledge transfer through the IP driven routes - such as patents, licenses and spin outs - referred to as "research commercialisation" in the literature (Perkmann et.al., 2013; Thursby and Thursby, 2002). A large number of countries followed this model, and whether directly or indirectly, influenced the spread of KTOs in universities across many countries (Bercovitz et.al., 2001; Ray and Saha, 2011). Although not subjected to a similar legislation, universities in the UK followed this pattern as well and started establishing KTOs, which became the organisational sub-units acting as the interface between researchers and users of research. To begin with, these KTOs largely concentrated on these IP driven commercialisation routes for bringing research closer to its users, but over recent years has increasingly explored other means as well.

In fact, extant research shows that the focus of university industry linkages has shifted from this unidirectional "research commercialisation" model to a bi-directional "academic engagement" model (Perkmann et.al., 2011; Perkmann et.al., 2013; Rossi and Rosli, 2013), where universities and industries (and others) are co-creators of research (Roux et.al., 2006). Such engagement can occur through a number of complementary channels, with the most popular ones being contract research, collaborative research and consulting. A number of studies (for example, Andersen and Rossi, 2011; Bruneel et.al., 2010; Perkmann and Walsh, 2008; Perkmann and Walsh, 2009; Phan and Siegel, 2006; Rosli and Rossi, 2016) have emphasized the multiplicity of channels and explored its implications. Henceforth, we use a similar terminology in this paper to distinguish between the two categories of knowledge transfer: the research commercialisation channel - encompassing, patents, licensing, university spin outs etc. - and academic engagement channels, which includes contract research, collaborative research and 
consultancies. The term "knowledge transfer" is used to collectively refer to all commercialisation and academic engagement channels.

Ambidexterity as a theoretical framework does not explicitly distinguish between multiple channels of knowledge transfer, although related literature has largely focussed more on commercialisation activities (Chang et.al., 2009; Chang et.al., 2016). However, the availability of a multiplicity of channels, including academic engagement alternatives, can have implications for universities. Universities have been shown to be heterogeneous in many respects, including research breadth and specialisation. Hence, prioritising certain channels over others - especially between research commercialisation and academic engagement - is an important consideration for any university (Rossi and Rosli, 2013). In fact, it has been shown that universities do explore alternative paradigms of knowledge transfer and are willing to evolve with time (Sharifi et.al., 2013; Locket et.al., 2015). Given the availability of alternative pathways, and the inherent heterogeneity amongst the universities themselves, it could imply that different universities adopt different pathways of knowledge transfer, depending on local university level contextual factors (Sengupta and Ray, 2017).

From the university's own perspective, the twin pillars underlying ambidexterity (research and knowledge transfer) do not automatically translate into "new business". A long term view and appropriate resources also need to be in place for research to be "translated" and transferred to potential users (Hughes and Kitson, 2012). This can create pressures and conflicts when it comes to resource allocation and internal policy regarding the direction a university wishes to take. Given finite resources, universities could face a difficult choice in resource allocation between meeting the relatively short term objectives of knowledge transfer versus the longer-term research objectives (Dasgupta and David, 1994). And even if a new piece of research or technology has commercial potential, it usually requires additional time and resources to be invested for translation into a proof of concept which is acceptable by its final users (Hughes and Kitson, 2012). Hence it is crucial that the underlying inter-temporal links between research and knowledge transfer is uncovered to explore whether these tensions persist over time.

The literature has examined this link to quite a large extent, but results remain ambiguous. Conventionally, it may appear that research output (in the traditional form of academic publications) would have an inverse relationship with industry engagement, given the tensions between the norms driving fundamental research and applied research relevant (Dasgupta and David, 1994) and the fact that resources of universities are finite. Yet, previous studies do indicate that research and knowledge transfer levels are positive related (Dutrénit et.al., 2010; Lee, 2000; Perkmann and Walsh, 2009, Perkmann et.al., 2011). Let us examine this in further detail.

On an individual researcher level, academic seniority and success seem to be positively related to both commercialisation and academic engagement. For instance, Bozeman and Gaughan (2007), D'Este and 
Perkmann (2011), Gulbrandsen and Smeby (2005), Haeussler and Colyvas (2011), all indicate that more senior and/or more productive (in terms of research output) are more likely to engage in commercialisation and engagement activities. Perkmann and Walsh (2009) show that research output may differ in nature yet maintain a high quality if it arises out of industry collaborations.

In contrast to the above findings based on individual researchers, the link between organisational research quality and some forms of knowledge transfer activities - typically academic engagement - is often contradictory (Perkmann et.al., 2013). For instance, D'Este and Patel (2007), found a negative relationship at the organizational level between the two, although overall the impact of organizational characteristics is weaker than individual characteristics (which have a positive impact). In contrast, Wright et.al. (2008) show that it is not just the top level universities, but mid-level research universities can successfully engage with industry as well, although they face greater constraints. And Perkmann et.al. (2011), uses organization level data to show academic quality is positively related to academic engagement in selected disciplines, but could possibly negative in some others. This ambiguity in findings is indeed surprising, given that academic engagement is ultimately driven through knowledge creation in partnership with external stakeholders (Roux et.al., 2006).

On the other hand, the relationship between organizational research performance and commercialisation has been found to be largely positive (O'Shea et.al., 2005; Perkmann et.al., 2013). Interestingly, Crespi et.al. (2011) find that academic patenting and research are complements up to a certain level of patent output, after which they become substitutes. The source of this substitution effect has usually been attributed to re-orientation of research agendas towards a more "applied" focus (Florida and Cohen, 1999) and to the tendency of enclosing research output within closed boundaries (Hane, 1999).

Thus, the relationship between research and knowledge transfer, particularly the academic engagement component, remains unclear at the organisational level. At the same time, it is difficult to conceptualise that new knowledge transfer arrangements can be consistently and sustainably carried out in a vacuum or without new scientific breakthroughs acting as the base for new collaborative research with nonacademic stakeholders.

\subsection{The role of time}

We predict that these contradictions can be explained if we consider that it takes time (and other resources) to translate a piece of research output into a form suitable for practical use (Hughes and Kitson, 2012). This is where the knowledge transfer pillar of ambidexterity becomes key, as they provide the relevant support and the infrastructure (such as KTOs and staff dedicated to knowledge transfer) for this translation to take place (Ambos et.al., 2008; Belenzon and Schankerman, 2009, Chapple et.al., 2005; Sharifi et.al., 2013). This is especially relevant at the level of the organisation, as an appropriate "ecosystem" of knowledge creation and transfer may become necessary for research to flow through the appropriate channels sustainably (Roux et.al., 2006). This points towards "time" as 
being an important input into how basic research (or a portion of it) gets converted into knowledge transfer outcomes, and which has been missing in the extant literature.

Let us now explore the role of time as an element in this relationship in more detail. Academic research outputs usually take very standard forms - for instance journal articles, books, manuscripts, dissertations etc. Not all outputs are considered to be of equal "value" in terms of quality or contribution to specific fields of research, and discipline specific standards of judging the quality of output do exist (such as the widely accepted journal and publisher rankings based on citation metrics and impact factors). It is generally accepted that individual researchers, departments, and universities who are able to attain higher quality scores through their associated research outputs are able to reap the rewards of recognition and reputation that are forthcoming as a result. At the organisational level, it is not just quality, but the overall quantity, intensity and variety of research areas that are also associated with overall reputational impact.

It is our contention that the relationship between research output (both quality and quantity) and knowledge transfer needs to take the temporal dimension into account. Previous sector studies have shown that there is a significant lag between the point in time when a set of research results are finalised and that at which it is put into practise, given the complexities and delays involved in the "translation process" (Morris et.al., 2011). For a university and its KTO, such delays may arise in the natural process of finding a "buyer" for the research or in the process of managing relationships and negotiations, even when a buyer has been found (Hugh and Kitson, 2012). Another factor which may delay the transfer process and that has recently gained attention, both in the literature and in policy circles, is the lack of resources within universities to carry out the "technology validation" process (Cartalos et.al., 2016). This is often a key step in the knowledge transfer process, through which, a prototype technology is adapted for actual integration based on the user's needs (Landry et.al., 2007). Finally, lack of resources within the KTO (Phan and Siegel, 2006) or lack of experience (Ambos et.al., 2008; O'Shea, 2005) with regard to particular research outputs may also result in a time lag between the production of research and its valorisation through knowledge transfer.

For all these reasons, examining the impact of research on knowledge transfer necessitates a dynamic approach over a static one. This leads us to hypothesize, that at the level of the university, the relationship between prior research and the various knowledge transfer channels is positive (H1).

H1: The research pillar of a university reinforces its knowledge transfer pillar over time, that is, past research output positively impacts future knowledge transfer activities.

\subsection{Impact of university's size and reputation on ambidexterity}

As organisations evolve and mature within an increasingly demanding environment, the need to develop specialised capabilities and infrastructure through which both exploitation and exploration activities can be sustained, becomes critical (Tushman and O'Reilly, 2002; Tushman and O'Reilly, 1996). 
Ambidextrous organisations, are able to reconcile contradictory structures, processes and aims successfully while carrying out both activities on an equal footing. For a university, this implies being able to use its traditional research outputs (publications, patents and any other university owned intellectual property) for conversion into commercial outputs for practitioners through knowledge transfer channels (Ambos et.al., 2008). A large volume of literature has been devoted to the antecedents of organisational ambidexterity in general (O'Reilly and Tushman, 2013), we can identify some which are of relevance to universities in particular.

Firstly, studies have shown that ambidexterity is generally positively associated with performance (Gibson and Birkinshaw, 2004 and Han and Celly, 2008). These studies have uncovered the relationship between ambidexterity and performance both at the organisation level as well as at individual levels. However, the impact of ambidexterity on performance has been seen to be contingent on environmental factors - such as access to resources within uncertain or competitive environments (O'Reilly and Tushman, 2013). There is also some evidence to show that larger organisations are relatively more adept at implementing ambidexterity than smaller ones (O'Reilly and Tushman, 2013; Lubatkin et.al., 2006; Lin et.al., 2007). And finally, some studies have been able to capture the evolution in ambidexterity over time, in terms of how organisations adapt (House and Price, 2009) or how they may fail in either exploitation or exploration or in both (Daneels, 2011). These studies point towards organisational size or scale being associated with the ability to be ambidextrous.

Ambos et.al. (2008) highlight the role that "reputation" or scientific excellence of the department and the university as a key factor in enhancing the likelihood of knowledge transfer. Studies have shown that greater reputation of scientific excellence is associated a higher degree of knowledge transfer (Perkmann et.al., 2013; Wright et.al., 2008). At an organisational level, reputation of scientific excellence can be treated as a "non-rivalrous resource", which enables the universities to carry out commercial exploitation without compromising their research credentials (Ambos et.al., 2008).

Hence in the case of universities, as they grow in size and in reputation, it is expected that their ability to be ambidextrous grows as well. On one hand, this naturally implies that research outputs are translated into knowledge transfer pathways more effectively and efficiently (Ambos et.al., 2008). On the other, it also implies a higher degree of "path dependence" in each of the pillars of ambidexterity that is, mature pillars of ambidexterity are able to operate with a certain degree of independence from each other. In fact, path dependence is increasingly being recognized within the organisational studies literature as a key factor which shapes organisational practises and behaviour over time (Sydow et.al., 2009).

Knowledge creation and management, technology growth and innovation, in general, have been known to exhibit path dependence, through complex intra and inter-organisational and social processes (Coombs and Hull, 1998; Ruttan, 1997; Zahara, 2008). The case of a university is no exception, where 
reputed individuals, departments and the organisation itself, are able to benefit from a virtuous cycle greater reputation attracts talented individuals and valuable resources, which in turn enhances their research reputation even further (Börner et.al., 2004; Mazloumian et.al., 2011; Petersen et.al., 2014). A similar cyclical process is expected to occur within the knowledge transfer pillar as well, where past successes, experience and reputation aid in creating opportunities for knowledge transfer in the future at a greater rate than universities which do not benefit from similar scale or reputation (Levin and Cross, 2004; Santoro and Gopalkrishnan, 2000). This may possibly arise as a result of greater experience and streamlined processes in KTOs (Ambos et.al., 2008; Siegel et.al., 2003), better embedding of the organisation within stakeholder networks (Reagans and McEvily., 2003; Perez and Sánchez., 2003) or establishment of career pathways of individual researchers more exclusively focussed on knowledge transfer led research activities .

Howell and Annansingh (2013) show that knowledge generation and sharing is path dependent in the context of cultural differences between two universities in the UK, when one is within the "Russell Group" and the other outside it. ${ }^{2}$ Extending Howell and Annansingh's (2013) argument, we posit that a degree of path dependence may be present in each pillar once they have attained a certain maturity. As universities grow in size, and as their reputations are established more universally, both pillars of ambidexterity attain a degree of self-sufficiency. In other words, among larger and/or reputed universities, we would expect a weakening of the link between research and knowledge transfer outcomes, leading to greater structural separation between the two (Birkenshaw and Gibson, 2004). This is expressed in the following hypothesis.

H2. Size and reputation of a university negatively moderate the link between past research and future knowledge transfer.

The size of the university is measurable quite reliably along a number of dimensions, such as number of staff employed, number of students graduating at various levels, the number of research active and teaching departments etc. Reputation is however is often subjective and may depend on the departments or disciplines being considered. In general, universities exhibit a high degree of variation in performance in terms of research (Geuna and Nesta, 2006; Hewitt-Dundas, 2012) and in knowledge transfer outcomes (Kitagawa et.al., 2016; Sanchez-Barrioluengo, 2014). Various sector level studies indicate that this heterogeneity is in part explained by the Russell Group, the membership of which generally coincides with significant above-average performance across all core missions, including research and knowledge transfer (Hewitt-Dundas, 2012; Sengupta and Ray, 2017). The Russell Group universities, on average, are older than their counterparts outside their group. While universities in the UK started establishing dedicated knowledge transfer frameworks and offices in the 1980s and 1990s,

\footnotetext{
${ }^{2}$ The Russell Group of universities consisting of 24 self-selected organisations, consistently ranked high in performance and reputation within the higher education sector, and have often been referred to as the elite universities in the UK (Hewitt-Dundas, 2012).
} 
many of the early movers in this area are also current members of the Russell Group. ${ }^{3}$ At the same time, sectoral data shows that among their peers, these have traditionally received the largest share of knowledge transfer related funds from public and private sources as well. ${ }^{4} \mathrm{~A}$ comparison between the Russell Group and the UK sector as a whole (Table 1), provides a clear distinction between this group and the rest along a number of dimensions. For the purpose of this paper, we consider the Russell Group membership as a proxy for organisational reputation.

[Insert Table 1 here]

\subsection{Knowledge transfer as a mediator}

Given an increasingly competitive and complex environment within the higher education sector, ambidexterity is increasingly becoming an essential capability for universities. However, given resource constraints that a university may face and conflicting priorities between its alternative missions (Ambos et.al., 2008; Dasgupta and David, 1994; West, 2008), building an ambidexterity at an organisational level may be challenging, especially for smaller and medium scale universities (Bercovitz and Feldman, 2003; Markman et.al., 2005). At the same time, a high degree of path dependence in research and innovation in organisations (Coombs and Hull, 1998; Ruttan, 1997), can result in organisational resistance towards strengthening of the ambidexterity framework (Ambos et.al., 2008). However, the scale of this trade-off or conflict may be mitigated to some extent if there exists a natural mechanism through which the pillars of ambidexterity may reinforce each other.

Previously, with regard to H1, we explored the possible mechanisms through which research output may directly impact knowledge transfer positively. In order to explore any possible feedback between research and knowledge transfer fully, we also have to ask if knowledge transfer in itself is able to reinforce research. Perkmann and Walsh (2009), using qualitative techniques, show a positive impact of university-industry collaborations on the number of publications at the individual level within the engineering discipline, especially in collaborative research. At the same time, Dutrénit et.al. (2010) in a micro level study of researchers and firms in Mexico are able to show that researchers can extract intellectual benefits (new ideas for research, reputation, knowledge, inspiration) from both commercialisation and engagement activities. In the context of ambidexterity, Ambos et.al. (2008) indicate that this relationship is actually quite complex. While ambidextrous individuals do exist, and they are able to maintain high standards of research and commercial output, they are few and far

\footnotetext{
${ }^{3}$ The UK University Commercialization Survey: Financial Year 2002.

${ }^{4}$ For instance, the Higher Education Innovation Fund (HEIF) has been initiated to encourage and support knowledge transfer in universities in the UK and are considered to be a key public funded support mechanisms to build knowledge transfer capacity. In the HEIF3 (2004-2007) and HEIF4 (2008-2011) funding rounds, the Russell Group as a whole received over $26 \%$ and $20 \%$ of the total HEIF allocations respectively. At the same time, the Russell Group received the substantially higher levels of private funds through knowledge transfer than the rest of the sector (Table 1).
} 
between. In fact, they find that most individuals choose one of the two alternatives, and rarely both; and this choice depends on both the motivation and perceptions of individual researchers.

Hence it is unclear how ambidexterity (or the lack of it) at individual levels may impact on the relationship between current knowledge transfer activities and the overall research potential of the university, a question of key importance to both university management and policy makers. To the extent that each type of activity requires investment in a non-substitutable resource, there is a clear trade-off between investing in knowledge creation and knowledge transfer. However, previous research points towards directions through which knowledge transfer can play a mediating role in connecting past research output to future research output, at an organisational level.

In effect, that would mean that a part of the current research output is channelized through current knowledge transfer activity. This is quite apart from the direct impact of previous research through path dependence, as discussed above. While previous literature has shown that (academic) research collaborations play a mediating role in enhancing individual research productivity (Lee and Bozeman, 2005), here the focus is on whether interactions with non-academic partners play a similar role at the university level. A number of mechanisms exist, through which this is possible.

Academic engagement activities such as collaborative and contract research, can and do lead to new knowledge creation at the same time (Perkmann and Walsh, 2008; Perkmann and Walsh, 2009; Schartinger et.al., 2002). While it may directly lead to generation of new applied outputs such as patents (Agrawal, 2006), it is also conceivable that more standard research outputs, such as academic publications may arise out these relationships as well (Salter and Martin, 2001). In fact, prior research points towards significant gains that individual researchers can appropriate from university-industry relationships - whether through an open innovation framework (Powell et.al., 1996), or through joint research centres and other public-private partnerships (Macpherson and Ziolkowsky, 2005) - and hence may wish to sustain such relationships in the future (Perkmann and Walsh, 2009).

Hence we hypothesize that knowledge transfer plays a positive mediating role between research outputs produced at two different points in time.

H3: The relationship between past and current research output in a university is positively mediated by current levels of knowledge transfer.

The hypotheses presented above attempt to capture the dynamic relationship that exists between the two pillars of an ambidextrous university In effect, the analysis in this paper builds support for the conceptual model presented in Figure 1, indicating the inter-temporal connection between research and knowledge transfer (H1), the impact of university level characteristics such as scale and reputation on this connection $(\mathrm{H} 2)$, and the feedback between the two pillars (H3). 


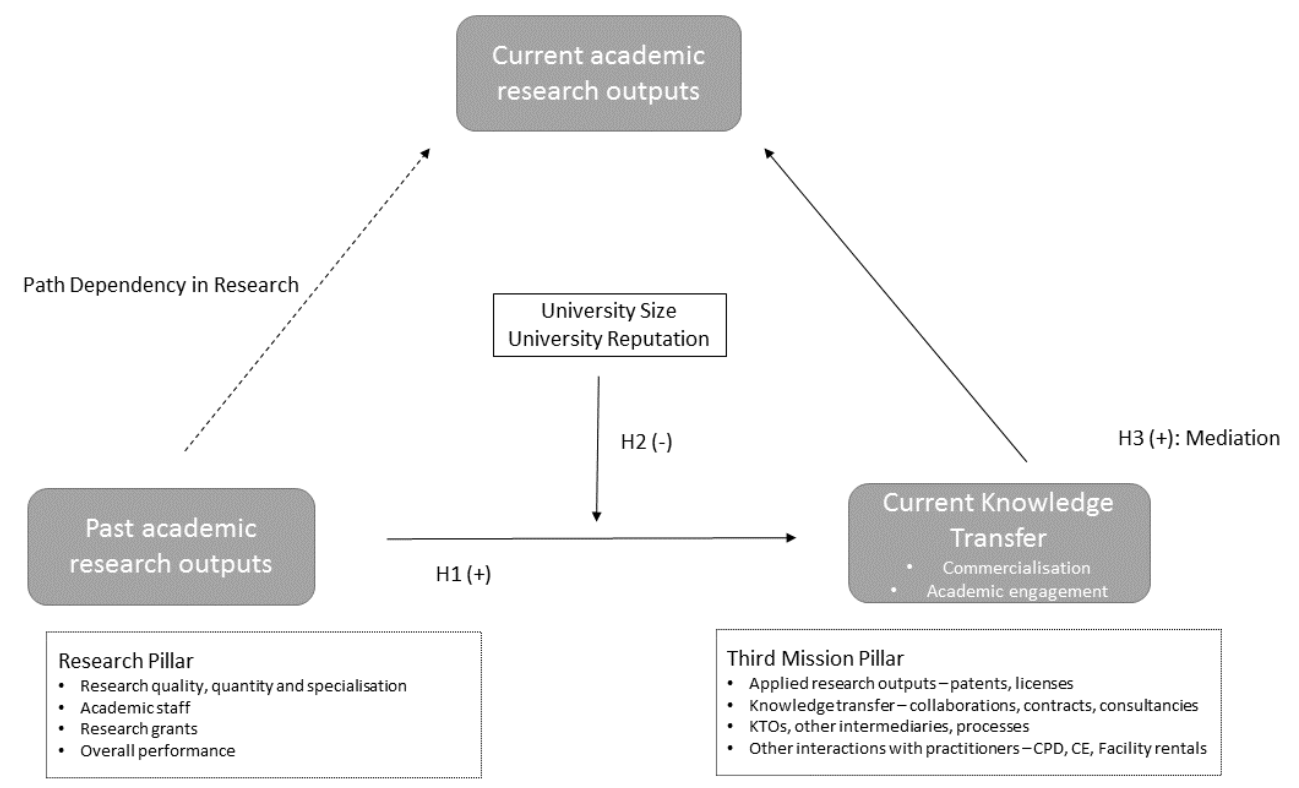

Figure 1: Conceptual model underlying the relationship between the research and third mission pillars in an ambidextrous university.

\section{EMPIRICAL DESIGN}

\subsection{Data Sources}

Secondary data for the analysis has been obtained from multiple sources in the UK, with the Higher Education Business and Community Interaction (HE-BCI) surveys providing the bulk of it. The data is collected and maintained by the Higher Education Statistics Agency (HESA) in the UK. HESA also collects and makes available data on institution specific characteristics, which are used in our analysis. In order to measure research output, we use the results of the nationwide research evaluation carried out in the UK every six years. We use the results from the 2008 (the Research Assessment Exercise or the RAE) as well as from 2014 (the Research Excellence Framework or the REF) assessments to compute the overall research performance of institutions of HE across the UK.

All variables used in our analysis are listed and described in Table 2, under the categories of endogenous, exogenous and control variables. Research output measures are from years 2008 and 2014 (calculated as described below), all other key covariates (including knowledge transfer measures) are from the intervening years 2009-10, 2010-11 and 2011-12..$^{5}$ In order to discount yearly variations, we

\footnotetext{
${ }^{5}$ Data from the years 2012-13 and 2013-14 were not available at the time this research was conducted. It is also likely that outcomes are not relevant for research output in 2014, given the proximity to the REF 2014 deadline, which was towards the end of the calendar year 2013. Additionally, the HE-BCI data from years prior to 2008 were qualitatively different. The data prior to 2008 had a smaller number of universities who participated in the data collection, and a smaller number of variables available. Hence we use the data from the intervening years between the two most recent research assessments in the UK.
} 
consider the average of these three years for these variables (except cumulative patent portfolio). Additionally a set of knowledge transfer variables prior to the RAE 2008 is also used as controls. Once all datasets were combined and cleaned for missing values ${ }^{6}$, we ended up with 129 out of 159 degreeawarding and research active institutions of higher education in the UK (excluding further education colleges).

\section{[Insert Table 2 here]}

\subsubsection{Research Output}

Both the RAE 2008 and the REF 2014 report the number of ranked publications in academic peer reviewed journals across all research active departments and disciplines for each university, which appeared in the intervening years between the previous assessment and the current one. For the RAE 2008, this includes research outputs published between January 2001 to December 2007; and the REF 2014 includes research outputs published between January 2008 and December 2013. ${ }^{7}$ Within both assessments, discipline specific journals are ranked from 1 to 4 , where 1 is the lowest and 4 is the highest rank. It also reports the number of academic members in each department, whose publications are being considered in the evaluation, i.e. who have been considered as being research active.

We use the publication ranks and associated number of publications across all departments in a university to compute a department specific score of research output per university. The departmental scores are then aggregated to compute an overall university specific score. The formula for calculating a research output score $R_{i}$ for university $i$ can be summarized as:

$$
R_{i}=d_{i} \times \operatorname{median}_{j}\left\{f_{i j} \times\left(\sum_{k} k \cdot p_{i j}(k)\right)\right\},
$$

where, $f_{i j}$ is the number of active researchers in department $j, p_{i j}(k)$ is the percentage of publications with rank $k \in\{1,2,3,4\}$, submitted for evaluation from department $j$ in university $i$ and $d_{i}$ is the total number of academic departments who have featured in the RAE and the REF submissions from university $i$.

The above formula takes into account not just the number of articles published in ranked journals, but weighs the contribution of each publication with the relevant rank of the journal itself, as recognized in each evaluation round. It awards departments having larger number of active researchers but at the same time, a median measure (instead of a mean) ensures that the university level research scores are not

\footnotetext{
${ }^{6}$ Majority of the missing observations are due to their unavailability in the RAE2008 and/or REF2014 datasets. Not all institutions submitted to these evaluation exercises, and in some cases institutions merged in the intervening years. The rest of the missing observations arise due to random missing values in the HESA data sets. The resulting dataset of 129 observations is a fully complete one with no missing data or discrepancies.

${ }^{7}$ See http://www.rae.ac.uk for RAE 2008 and http://www.ref.ac.uk for REF 2014 details regarding submission criteria and results.
} 
biased by departments at extremes of the performance scale. Finally, a university with a larger number of research active departments get rewarded over those which have narrower focus. ${ }^{8}$ This provides us with two separate measures of the volume of research output controlled for quality for every university - one for 2008 and the other for 2014. Figure 2 presents the distributions of research output across the entire cross section of universities in our data, for RAE2008 and REF2014.

Additionally, aggregate income from Research Councils UK (RCUK) for the three years 2009-10 to 2011-12, is considered as a covariate in the analysis (see Figure 3 for frequency distribution of the average across the 3 years in our data).

A university's applied research focus (current and historical) is indicated through its performance in the traditional commercialisation. Historical performance of the university in terms of applied research is measured by its cumulative patent portfolio of all live patents in the year 2011-12 (see Figure 4 for the distribution). Additionally, we also consider the average number of patents granted and average number of active licenses held (including with its own spin out companies) by the university between years 2009-10 to 2011-12. Figure 5 provides a distribution of the average number of licenses (left) and the average IP income per license (right).
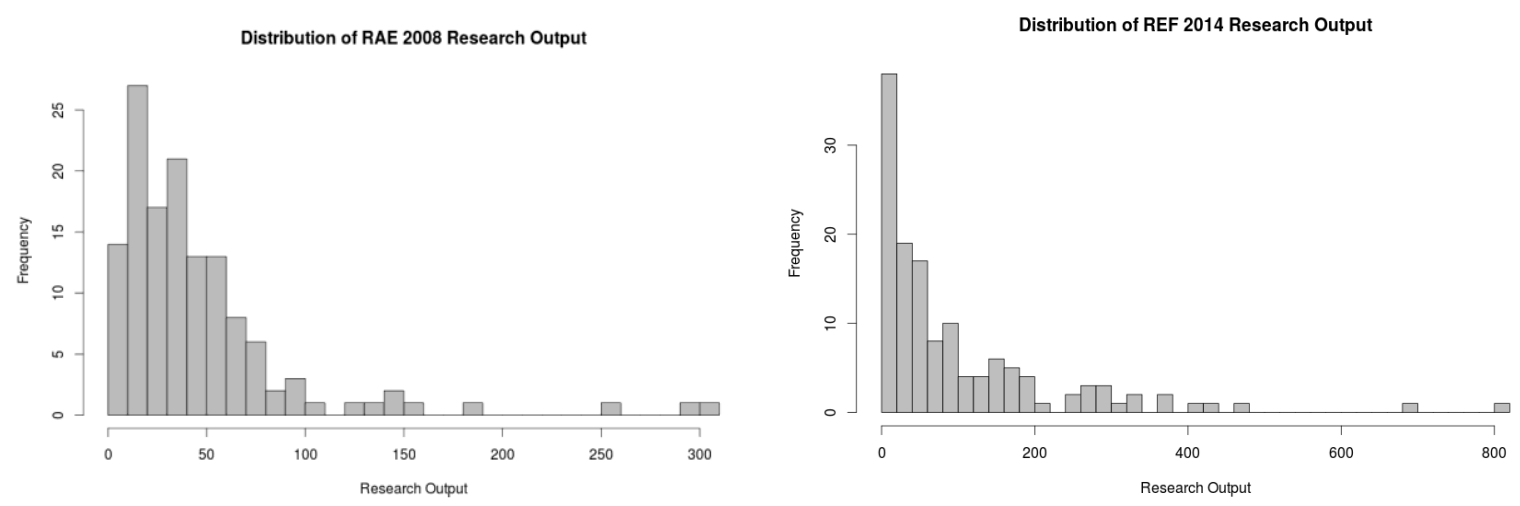

Figure 2: Frequency distribution of research output in 2008 (left) and 2014 (right).

\footnotetext{
${ }^{8}$ Given that the unit of analysis here is the university, this formula appropriately captures both the volume and quality of academic research output at the level of the organization. An alternative specification is to use two separate measures of research output - one, research quality represented by the median departmental score and two, research breadth, represented by $d_{i}$ as two separate university specific measures. However, the former is not a measure of university level research output, but measures a representative department's research from a given university. Our measure in effect captures both quality and quantity of research in one organization level score, and is more appropriate for the subsequent analysis.
} 


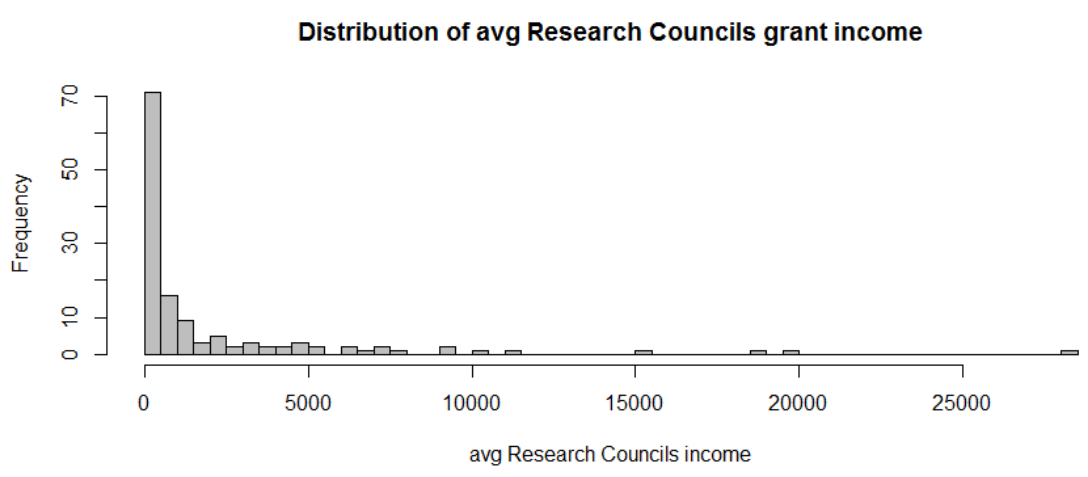

Figure 3: Frequency distribution of average research councils income, 2009-11 to 2011-12.

Distribution of cumulative patents 2011-12

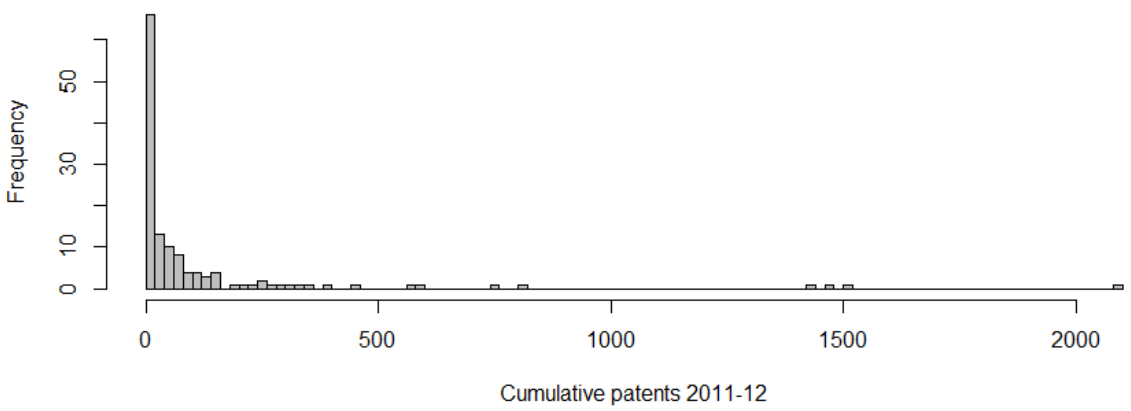

Figure 4: Frequency distribution of cumulative patent portfolio, 2011-12.
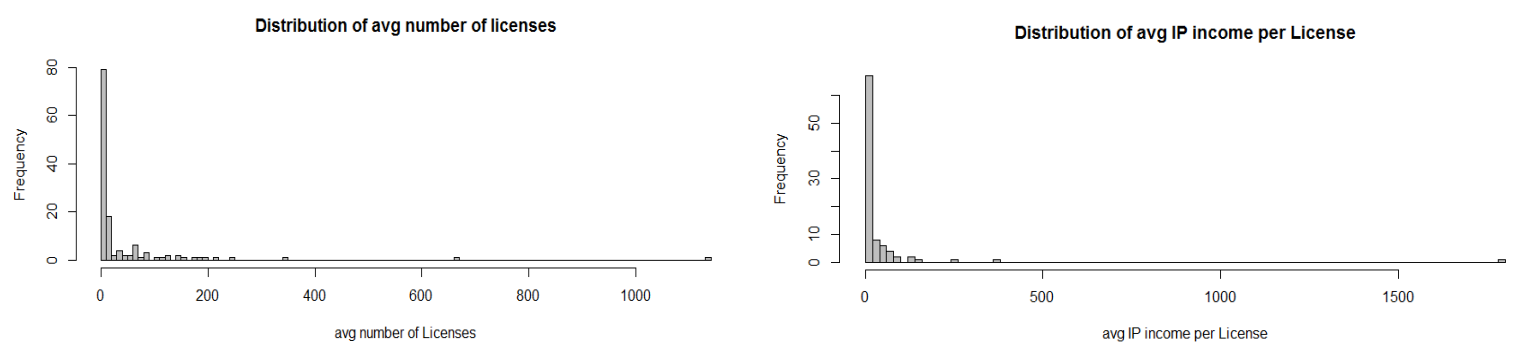

Figure 5: Frequency distributions of average number of licenses (left) and average IP income per license (right), 2009-10 to 2011-12.

\subsubsection{Measures of Knowledge Transfer}

Research commercialisation and academic engagement performance is measured using incomes from each of the relevant channels within these categories, as reported in the HE-BCI dataset. The data that we use in the analysis contains the following income variables, averaged over the three years 2009-10, 2010-11 and 2011-12: IP income (includes income from licensing and spin outs), Collaborative income, 
Contract income and Consulting income. The frequency distributions of all these four income measures are provided in Figure 6.

There are two issues to note regarding measures of knowledge transfer used in the data. First, the HEBCI data also provides the equivalent number of contractual agreements under licensing, contract research and consulting. However, this is not included for collaborative research, for which only the income is provided. Hence, we use the incomes from each channel as a measure of the volume of activity in each, which indicates the "value" of each channel to each university, and to a lesser extent, the "volume". Secondly, knowledge transfer activity from 2009 to 2012 overlaps with research output from REF 2014 to some extent (see section 3.1.1 above). ${ }^{9}$

\subsubsection{Control Variables}

In order to capture the heterogeneity across organizations, a number of university specific control factors are included in the analysis. First of all, we include knowledge transfer incomes from previous years to control for previous knowledge transfer performance. In particular, averages of IP, contract, collaborative and consulting incomes from years 2005-06 and 2006-07 are included. Secondly, apart from commercialisation and knowledge exchange activities, universities often engage with nonacademic partners through other means not involving research, such a providing specialised and bespoke training, providing facilities and lease of equipment and space etc. Such interactions could potentially help strengthen existing links, or enhance the likelihood of future links. Not all universities engage in such interactions equally, and hence this variation needs to be accounted for. These are captured through the inclusion of CPD income and Facilities income in the analysis.

Additional university level control factors included are the size of the full time and part time academic staff, age of the university and finally, the dummy variable indicating membership in the Russell Group.
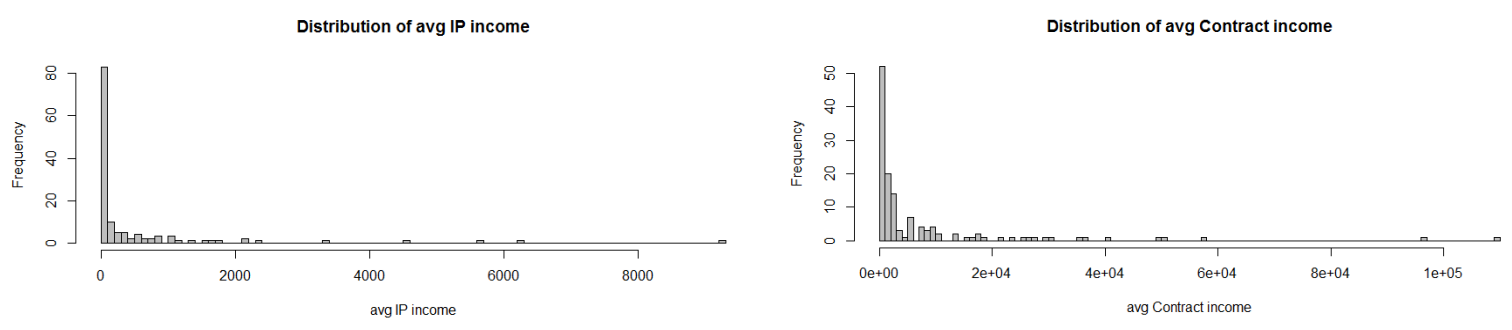

\footnotetext{
${ }^{9}$ This limits the extent to which we can test the impact of current knowledge transfer on "future" research, and hence the relevant hypotheses ( $\mathrm{H} 2$ and $\mathrm{H} 3 \mathrm{~b})$ consider only contemporary research.
} 

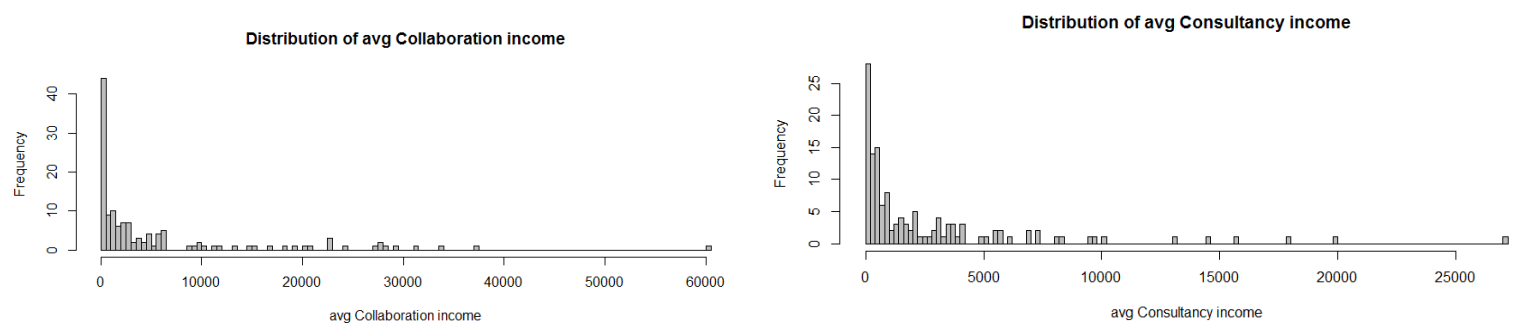

Figure 6: Frequency distribution of IP income (top left), contract income (top right), collaborative income (bottom left) and collaboration income (bottom right), averaged over 2009-10 to 2011-12.

\subsection{Models}

The empirical models used in the analysis are designed to test the hypotheses $H 1-H 3$, using a set of independent reduced form equations. Hypotheses $\mathrm{Hl}$ and $\mathrm{H} 2$ is tested using a set of channel specific independent regression equations as expressed in (1). For any given channel $C \in\{\mathrm{IP}$, Contracts, Collaborations, Consulting,$y_{C}(t)$ represents channel specific income (or its transformation) at time $t$. $X_{j}$ represents the explanatory variables including past research output $R(t-1)$, income from research grants, and indicators of success in commercialisation such as patents and license. $Z_{k}$ represents university specific control variables, $I_{k}$ represents the appropriate interaction terms and $u^{C}$ represents the equation specific random errors.

$$
\log y_{C}(t)=\beta_{0}^{C}+\sum_{i} \beta_{i}^{C} X_{i}+\sum_{j} \gamma_{j}^{C} Z_{j}+\sum_{k} \beta_{k}^{C} I_{k}+u^{C}
$$

The magnitude, sign and significance of the coefficient of $R(t-1)$ indicates the validity of $H l$, in a straightforward manner. To test $H 2$, we examine the coefficients of the interaction terms, where the interactions involved are between $R(t-1)$ and two other control variables - average staff size and the Russell group membership dummy. The interaction term $R(t-1) *$ avgStaffmeasures the moderation effect of a university's scale of operations ${ }^{10}$ and the interaction term $R(t-1) *$ Russell measures the same for Russell group membership. The overall impact of the moderation can be examined through the net marginal effect of $R(t-1)$ on the dependent variables, and these are represented graphically in the presentation of the results.

In order to test $H 3$, we first estimate equation (2).

$$
\log R(t)=\beta_{0}+\beta_{1} R(t-1)+\sum_{c} \beta_{c} y_{c}(t)+\sum_{j} \gamma_{j} Z_{j}+\sum_{k} \beta_{k} I_{k}+u
$$

\footnotetext{
${ }^{10} \mathrm{We}$ assume that academic staff size is reasonably good indicator of the scale of operations in a university. We found that non-academic staff numbers are highly correlated with academic staff members (coefficients over $0.9)$, and hence we did not include those separately in the model.
} 
The coefficient $\beta_{1}$ in (2) measures the path dependence in research output and $\beta_{c}$ 's represent the net association between the channel specific knowledge transfer incomes measured in time $t$ and the research output in the same period. We then carry out causal mediation analysis along the lines of Barron and Kenny (1986) and Imai et.al. (2010), for each knowledge transfer channel. Quasi-Bayesian Monte Carlo inference tests (Imai et.al., 2010) are used, with $R(t-1)$ as the treatment, $y_{C}(t)$ as the mediator, and 1000 simulation runs per knowledge transfer channel, to test the mediation effect specified in $H 3$.

We label the set of models estimated using Equation (1) as Model 1, and the one estimated by Equation (2) as Model 2.

\subsection{Simultaneity and Endogeneity}

The mutual correlations between the channel specific average incomes are significant and positive, with values approximately around the 0.5-0.6 range (Table 4). Although these values are not too high, they do point towards a full structural model specification through the simultaneous equation approach, instead of the reduced form adopted here in Model 1. In the simultaneous approach all four equations are estimated jointly, whereas the reduced form specification adopted here assumes mutual independence between the channels. However, a fully structural simultaneous equation model not only requires the use of suitable exogenous variables and instruments for model identification, it also requires an underlying theoretical structure which can provide suitable constraints on the parameters to be estimated. This requires further theoretical development on the relationship among the knowledge transfer channels themselves, and is currently outside the scope of this work.

However we do carry out a validation of our reduced form specification, by estimating the system using the Seemingly Unrelated Regression Equations (SUR) approach, which allows for the regression errors $u^{c}$ to be correlated between themselves. We find that the regression estimates are numerically similar as the independent OLS estimates (as expected, given that the right sides of all four equations are identical) and more importantly, the significance of individual coefficients do not indicate major divergence from the OLS results. This does provide a reasonable support for the independence assumption.

Endogeneity issues cannot be completely ruled out in the independent equation specification adopted. The lagged research output variable $R(t-1)$, ensures that endogeneity through reverse causality is minimized to a large extent. This is true for Model 1 where past research is the primary covariate of interest and to some extent in Model 2. However, unobserved university specific factors (such as, culture, strategy, experience of KTO personnel and other staff etc.) can still affect both sides of the equation, especially in Model 2, and which can result in endogeneity. The control variables account for some of this heterogeneity, but accounting for this form of endogeneity ideally requires a full panel of observations, which is beyond the scope of the data available to us. 
[Insert Table 3 here]

[Insert Table 4 here]

\section{RESULTS}

Table 3 presents the list of dependent variables and covariates in Models 1 and 2, Table 4 presents the results of the correlation analysis between the variables. The estimated coefficients and standard errors from Models 1 and 2 are summarized in Tables 5 and 6. The last row in the Tables presents the goodness of fit results. For significance of individual covariates, we report the robust heteroscedasticity consistent standard errors. The possibility of multicollinearity was checked for all regressions, and all the variance inflation factors (VIFs) came well within the acceptable range (in all cases VIF values were less than $5)$.

[Insert Table 5 here]

\subsection{Model 1}

Estimates from Model 1 are presented in Table 5. Two sets of estimates are provided for each channel - one includes the interaction of $R(t-1)$ with avgStaff size, and the other the interaction of $R(t-$ 1) with the Russell Group dummy. Our results indicate an unambiguous positive impact of academic research output on knowledge transfer across all channels at the university level. This can be seen in the positive and significant coefficients of $R(t-1)$ across all knowledge transfer channels in Table 5 (Models 1a-d). Thus we are able to claim that the research pillar indeed reinforces the knowledge transfer pillar at the organisational level, in support of $\mathrm{Hl}$. In terms of magnitude, it is in the contract research route that past research output has the maximum impact, followed by in collaborations and commercialisation. The least impact of past research is seen in consultancies.

It is natural to expect knowledge transfer is positively influenced by past research output, given that research forms the knowledge base which is channelized into commercialisation and academic engagement. At the same time, results also indicate that this is not a uniform relationship across the whole range of the data, but that it is moderated by a university's size and reputation. We find evidence of a negative moderating effect of both controls on the relationship between a university's past research and its future knowledge transfer activities. This can be seen in the negative and significant coefficients of the interaction terms in Table 5, which indicate a weakening of the link between past research and future knowledge transfer, and thus establishing $\mathrm{H} 2$. Figure 7 plots the impact of moderation of university's size (as measured by avgSize) and Figure 8 shows the same for Russell Group membership.

Figure 7 shows that, for organisations which are of larger size, the marginal impact of past research 
turns negative, for all channels. The pattern is similar for the reputation effect among the members of the Russell Group (Figure 8). In this case, the marginal impact of past research once again falls significantly, but turns negative only for commercialisation and contract research. The impact is negligible but positive for collaborative and consultancy routes.

These results imply that the research pillar strengthens the knowledge transfer pillar at the organisation level in case of both commercialisation and academic engagement, indicating complementarity between the two. However, the positive marginal effect of past research weakens significantly as universities grow in size and reputation, indicating a possible decoupling and substitutability between the pillars of ambidexterity. These patterns in the magnitude of the coefficients and in the moderation effects, have implications for university level strategy, when it comes to enhancing ambidexterity and we will come back to this point in the Discussion section later.
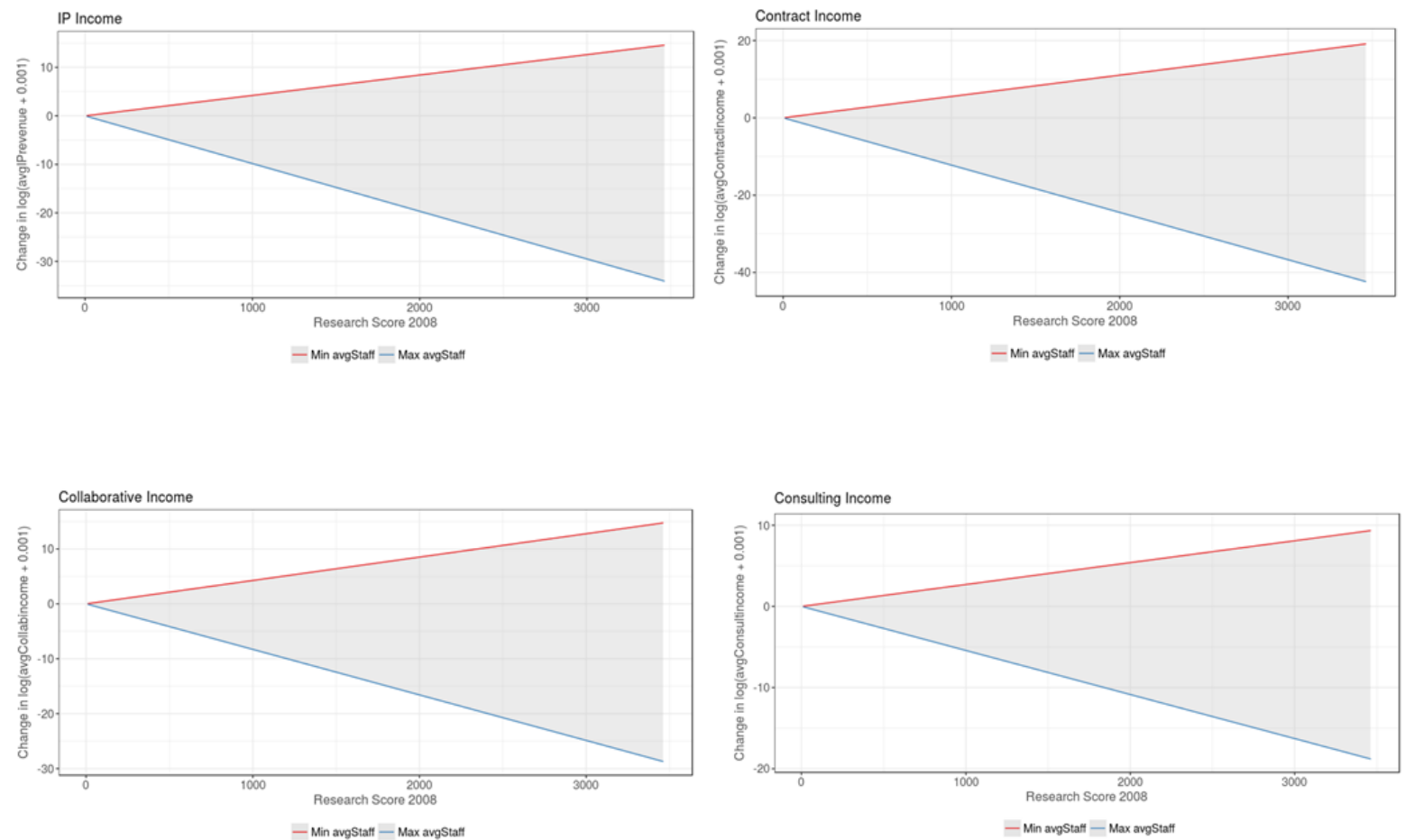

Figure 7: Moderation effect of staff size on the impact of past research on knowledge transfer.

Note that while actual past research is positively linked to commercialisation and academic engagement, related fundamental and applied research indicators do not show much significant impact on knowledge transfer. Only research grants (RC Income) are seen to positively impact income from collaborations, which is understandable given that collaborative income includes contribution of non-academic partner(s) in grant funded research projects. The number of new patents granted, the cumulative patent 
portfolio and active licenses held by an institution have no significant impact.

Moreover, the direct effect of average staff size is positive and significant, indicating a possible scale effect on knowledge transfer. Related to this is the Russell Group membership dummy, which captures the direct effect of reputation, although it appears weaker than the impact of size. Interestingly, among the past knowledge transfer income variables $y_{C}(t-1)$, none seem to have much impact on future income through the same channel. Among the other control variables, Facilities income, and to some extent CPD income, have positive association with knowledge transfer income. However, the age of the university has no bearing at all on any channel. These are potentially interesting findings with implications for ambidexterity within universities, which we discuss later.
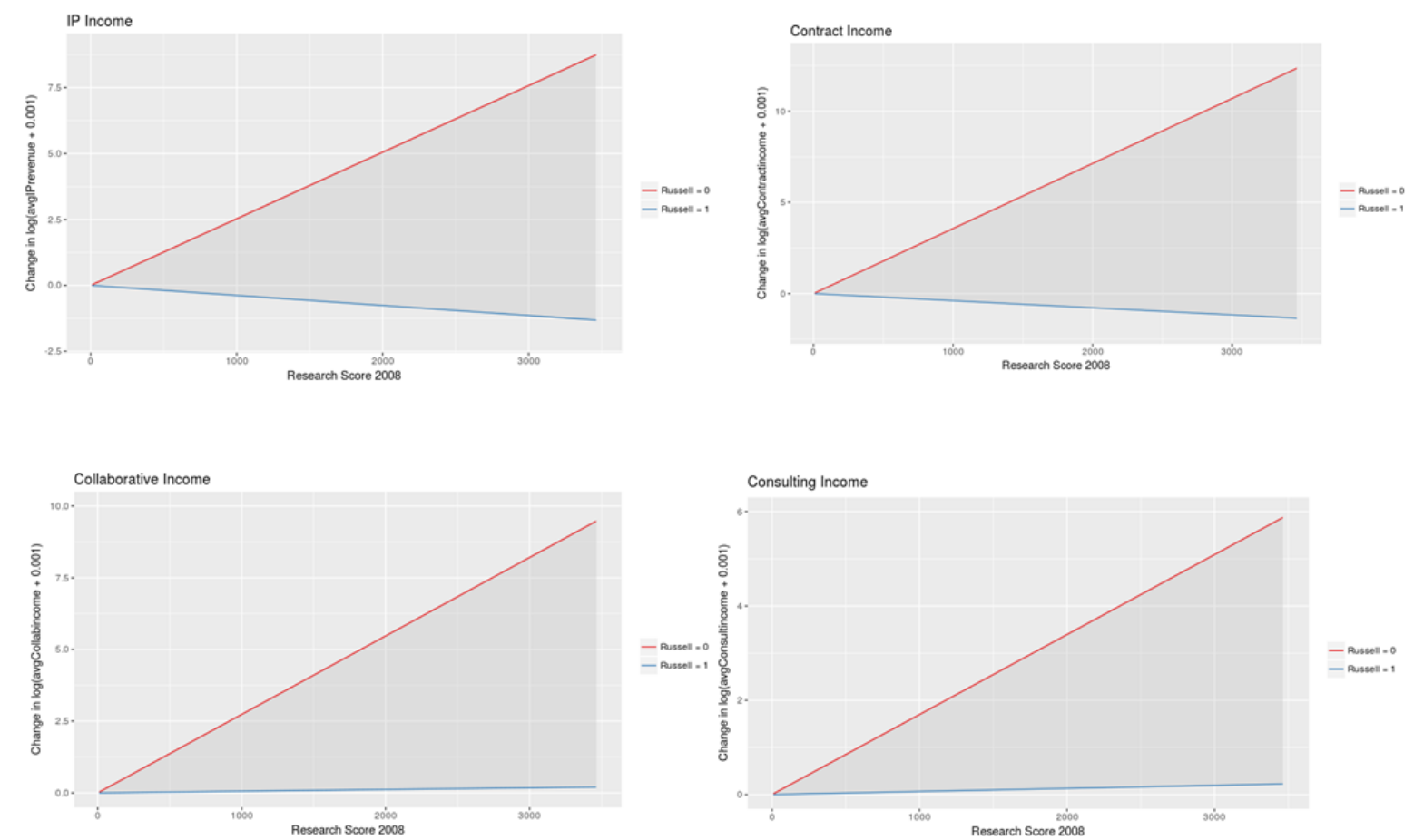

Figure 8: Moderation effect of Russell Group membership on the impact of past research on knowledge transfer.

\subsection{Model 2}

Estimates for Model 2 are presented in Table 6. The partial model (2a) estimates the impact of the control variables. When past research is introduced into the model (2b), its coefficient is seen to be positive and significant. This remains the same when the remaining covariates are introduced $(2 \mathrm{c})-$ indicating a degree of path dependence in research outcomes.

Among all knowledge transfer channels, only collaborations have a positive association with research output. Interestingly, the commercialisation channel is actually negatively associated with research, 
while contracts and consultancies do not seem to have any association. This is potentially an interesting finding, which we explore further in the Discussion section below. Among the control variables, we once again detect the scale effect of avgStaff, but no association with the reputation effect (Russell Group) could be seen in the full model. Both CPD income and Facilities income are positively associated with research but once again, Age is not.

Model 1 indicated a positive impact of past research on current knowledge transfer, and the Model 2 estimates indicate an association of current research with some channels of current knowledge transfer. This points towards a possible mediation role of the latter between past and present research, in support of $H 3$. In order establish the magnitude and significance of the mediation, we carry out a causal mediation analysis using the Quasi-Bayesian Monte Carlo inference method (Imai et.al., 2010), where $R(t-1)$ is the input (treatment) variable, $R(t)$ is the outcome variable, and the incomes across the four knowledge transfer channels are the proposed mediators. The channel specific equations in Model 1 and the full Model 2 are used for this analysis, with a 1000 simulation runs for each channel of knowledge transfer. Results are shown in Table 7, where we report the estimated sizes of the average causal mediation effect (ACME) of the particular knowledge transfer channel, the average direct effect (ADE) of past research and total effect combining the two. The treatment condition is to change the value of $R(t-1)$ from a value of 0 to 1 , in order to explore the impact on the mediators and the outcome. Two separate set of tests are carried out - (a) on the full sample of 129 universities and (b) on the non-Russell Group universities only.

Two interesting results emerge from this analysis. First of all, it is only academic engagement (mainly collaborations and consulting) which exhibit a small but positive and significant mediation effect, whereas the mediation role played by IP driven commercialisation channels is actually negative. Secondly, the exclusion of the Russell Group from the sample makes a difference in two ways - one, the (negative) role of commercialisation disappears and two, academic engagement mediates only via contracts replacing collaborations and consulting. However the size of this mediation through contracts is larger by a factor of 10 (although significant only at $10 \%$ ).

It seems that there are more opportunities for academic engagement channels to mediate positively between past and present research, the actual strength of mediation seems to be stronger within the nonRussell Group universities. Once again, we see that the Russell Group exhibit a greater degree of structural separation between research and knowledge transfer, which reduces the overall presence of mediation effect within the sample. However, once the Russell Group are excluded in the sub-sample, the importance of knowledge transfer as an effective mediator between past and future research increases significantly, and the channel of choice is contract research.

Hence we are able to establish $H 3$, but only with respect to academic engagement channels, but not for the research commercialisation channel. 
[Insert Table 6 here]

[Insert Table 7 here]

\section{DISCUSSION AND CONCLUSION}

Ambos et.al. (2008) explore the inherent tensions that exist between the research and commercial aims of a university, and show how ambidexterity at both organisational and individual levels can be used to resolve these. They show that the presence of a KTO, its experience and breadth of support are key factors are key predictors of commercial outcomes. Chang et.al. (2016) examine ambidexterity at the level of an individual and the department, and explore the positive role played by the department in enhancing research and commercialisation outcomes at individual levels, and at the same time show that university level characteristics may affect ambidexterity at both researcher and departmental levels. This paper explored ambidexterity at the organisational level and uncovered key dynamic inter-linkages between its pillars, providing an explanation of the mechanisms underpinning these linkages from the university's perspective.

We found that past research output has a net positive impact on knowledge transfer outcomes at the organisational level $(H I)$. However, the marginal impact of research on both commercialisation and academic engagement channels depend on the university's scale and reputation, which is dampened for universities which are larger in size and/or particularly reputed within the sector (such as the Russell Group in the UK). This dampening effect was found to be significant and large, to the extent that the marginal impact of research becomes negative in most cases (H2). In effect, this points towards a greater structural separation of the two pillars once the university has attained a degree of maturity, as indicated through size and reputation.

It is interesting to examine the magnitude of the main coefficients of $R(t-1)$ in Model 1 . As we saw above, for the whole sample, the coefficient is the largest for contract research, followed by collaborations, commercialisation and finally consultancies. From the point of view of a new piece of research or technology produced in a university, this implies that this marginal unit of research output has the highest likelihood of being transferred to practitioners through the contract research route, followed by collaborations, commercialisation and finally consultancies. From the university's point of view, this implies that contract research provides the best opportunity to strengthen its ambidexterity framework in a relatively short time frame, followed by others in the order above. For KTOs and staff directly involved in knowledge transfer in a university, this has implications on what type of contracts are prioritised and negotiated in the short term. Prioritising the contract research route could present a relatively easier short term option to enhance the organisation level knowledge transfer outcomes for a given research base. The results are somewhat different for elite universities such as those in the Russell Group - wherein collaborations are the preferred route. 
To identify the appropriate model of knowledge transfer from a longer term strategic view, one must consider its role in enhancing research as well. Channels that positively reinforce research will create a virtuous cycle - a large research base leads to greater knowledge transfer, some of which, in turn further augments the research base and so on. We find a significant effect of academic engagement channels in positively mediating between research outcomes from two different points in time $(H 3)$. This is understandable given that, academic engagement, especially collaborations and contracts, involves some element of new knowledge creation. It is also possible that the income earned through academic engagement is then ploughed back into creating additional or enhanced research capacity, which impacts research output at a later date positively. It is however, the differences in the mediation effect of each channel (within academic engagement) that has implications for universities in the longer run. When elite universities are excluded from the sample (in this case the Russell Group), it appears that contract research is once again the channel of choice in enhancing the ambidexterity framework of a university in the longer run. However, when considering the whole sample, collaborations and consultancies, rather than contract research, which have a positive role in enhancing research outcomes, although the strength of this positive mediation is lower. It appears that it is the Russell Group which is driving this result for the whole sample, and the weakening of the mediation effect is due to the decoupling of the pillars of ambidexterity.

Turning to commercialisation, the findings are somewhat different. Past research is positively linked to income from commercialisation. However, patents and licenses are the primary medium through which IP is commercialised and it is indeed surprising that these do not affect IP income at the level of the university. The most likely explanation for this is that a large proportion of the IP income is being sourced from a few "big winners", i.e. technologies which are responsible for the bulk of the income either through royalties or sale of spin out companies. In the absence of license specific data from universities (which is generally not published), the best indicator of this lies in the distributions of the average number of licenses and average IP income per license, both of which are highly skewed towards zero (Figure 5). Interestingly, we find no evidence of a positive mediation effect of commercialisation on research, rather a negative effect when the Russell Group is included in the sample. This seems to suggest that some of these universities might have accumulated a large volume of non-performing intellectual property assets, useful neither for commercialisation nor for research. Our results confirm that universities may need to re-examine their commercialisation and entrepreneurial strategies in the future, (Geuna and Nesta, 2006; Siegel and Wright, 2015).

As mentioned earlier, the mediation impact found in our analysis is limited by the concurrent nature of knowledge transfer and the second round of research assessment outcomes in our data set. Ideally, one would require a third round of research assessment $(R(t+1))$ to fully uncover the feedback mechanisms and establish whether there is a direct effect (positive or negative) of knowledge transfer on research as well. However, the findings above do indicate that universities can choose to optimize 
their effort in certain directions, both in the short run and in the longer run.

Thus, when examined in the context of an ambidextrous university, our results provide evidence of a dynamic positive feedback between the academic engagement component of the knowledge transfer pillar and the research pillar of a university. Results seem to suggest that the links between the two are bi-directional, enabling a virtuous cycle, particularly through the academic engagement route - although in the absence of a third round of research output data, we are unable to confirm a direct causal link knowledge transfer to research outputs. Within the scope of our models, we find the direct impact of past research on future research output is large and outweighs the indirect mediated effect of knowledge transfer channels. This also implies path dependence in the research pillar through serial correlation of future outcomes with the past.

It is interesting to note that while the research pillar exhibits path dependence directly through serial correlation between outputs produced at different points in time, the structural independence of the knowledge transfer pillar is somewhat different in character. There is hardly any dependence on past outcomes, given the largely non-significant coefficients of $y_{C}(t-1)$ in Model 1, apart from contracts to a certain extent. Thus, while some universities are able to achieve a lesser degree of interdependence between the two, the way that research and knowledge transfer proceeds thereafter within the institution are probably quite different. This is an interesting finding and warrants further research into the mechanisms driving the differences in the nature of independence in the two pillars.

The results presented in this paper have an important bearing on how universities may develop and maintain ambidexterity as a matter of policy. While tensions between the two pillars of ambidexterity (Dasgupta and David, 1998) could still be present at all levels (individual, department etc.), our results show that universities need not be overly concerned about outcomes in the short or medium terms. We see evidence of a virtuous cycle between the two within a relatively short time frame of 6 years in the data. It is only in the case of IP driven commercialisation routes that this virtuous cycle seems to be missing, and in fact, indicates a negative impact of these channels in some cases.

Additionally, the effect of university specific control variables in the models is interesting in itself. Generally CPD and Facilities incomes show a positive association with both overall levels of knowledge transfer income (Model 1) and research output (Model 2). The first is in line with previous literature (Hewitt-Dundas, 2012), and indicates that linkages with industry forged through executive education and use of facilities and equipment can actually enhance income from overall knowledge transfer activities as well. However, it is also interesting to note that research output shows a positive association with income from these sources, even when controlled for past research. This is indeed a surprising result, and points towards new directions of enquiry on the longer term impact of liaison between universities and industry through alternative channels which do not involve knowledge transfer. Finally, we find that the age of the university has no bearing on its capacity to be ambidextrous, although size 
and reputation do. All of the above, point towards specific policy prescriptions for universities aiming to enhance their capability to be ambidextrous.

Consider the hypothetical situation of a university needing to make a policy decision on where to invest a unit of resource "at the margin", and the choices being, building research capability or investment into the growth of its knowledge transfer capacity. Our findings suggest that for most universities in the low to medium size range, and who are not at top in a reputation scale as an organisation, the priority should be in research. Once a research base has been created, contract research and to a lesser extent collaborative research, provide the most effective routes for strengthening their ambidexterity framework. Of course knowledge transfer framework and structures should be already in place (such as KTOs, trained personnel, suitable incentive schemes etc.), and is a necessary component in an ambidextrous university. However, they will benefit more in the long run if the investment of the marginal unit of resource is used to strengthen the research pillar rather than the knowledge transfer one. This prioritisation is significantly weakened for larger and/or reputed organisations, and the investment in either of these two pillars should be driven more by contextual factors. At the same time, investment in enhancing CPD offerings and in forging links with practitioners through use of facilities and equipment can also prove beneficial.

When it comes to a choice of choice of channels, it is contract research and collaborations which are the main drivers of the virtuous cycle between research and knowledge transfer. This is true across the sector, although the most effective channel depends on the size and reputation of the organisation. Combined with the previous point, this indicates that, within universities where the two pillars have decoupled to a greater degree, collaborative research actually acts as a bridge between the two, which contract research (given its more applied nature) is unable to achieve. This result indicates that while building up a robust portfolio of contracts and collaborations is the key towards raising the overall profile of a university.

In conclusion, this paper provides an understanding of the key mechanisms that drive the linkages between research and knowledge transfer, the two pillars of organisational ambidexterity in a university. We not only stress on the temporal element in this relationship, we also show how organisational antecedents of ambidexterity directly impact this relationship. Although, constraints on the data available currently limits our ability to fully uncover the temporal linkages, results point towards specific strategies which universities can adopt in their attempt to strengthen their ability to be ambidextrous organisations. 


\section{Acknowledgements}

This project was funded by the JNU-Essex Development Fund (JEDF) administered by University of Essex, UK and Jawaharlal Nehru University (JNU), India. The authors would like to thank Dr Janice Pittis and Ville Karhusaari from the Research and Enterprise Office at Essex for their constant support and access to the data. A special note of thanks to Dr Luis Figueroa, who as the Research Associate on this project at its initial stages, assisted in the data clean up. We are grateful to all participants of the ESRC sponsored Impact workshop held at University of Essex for very helpful comments and feedback. Finally, a note of sincere thanks to all anonymous referees whose detailed comments and suggestions helped us to improve the paper to a great extent.

\section{REFERENCES}

Agrawal, A., 2006. Engaging the inventor: Exploring licensing strategies for university inventions and the role of latent knowledge. Strategic Management Journal 27, 63-79.

Ambos, T.C., Mäkelä, K., Birkinshaw, J. and D’Este, P., 2008. When does university research get commercialized? Creating ambidexterity in research institutions, Journal of Management Studies 45(8), 1424-1447.

Andersen, B. and Rossi, F., 2011. UK universities look beyond the patent policy discourse in their intellectual property strategies. Science and Public Policy 38 (4), 254-268.

Belenzon, S., and Schankermann, M., 2009. University knowledge transfer: Private ownership, incentives and local development objectives. Journal of Law and Economics 52(1), 111-144.

Bercovitz, J., Feldman, M., Feller, I. and Burton, R., 2001. Organizational structure as determinants of academic patent and licensing behaviour: An exploratory study of Duke, Johns Hopkins, and Pennsylvania State Universities, Journal of Technology Transfer, 26, 21-35.

Bhattarcharjee, Y., 2006. Industry shrinks academia support. Science 312(5774), 671.

Birkenshaw, J., and Gibson, C., 2004. Building ambidexterity into an organization. MIT Sloan Management Review 45(4), 47-55.

Boehm, D.N. and Hogan, T., 2014. 'A jack of all trades': The role of PIs in the establishment and management of collaborative networks in scientific knowledge commercialisation. Journal of Technology Transfer 39(1), 134-149.

Börner, K., Maru, J.T. and Goldstone, R.L., 2004. The simultaneous evolution of author and paper networks. Proceedings of the National Academy of Sciences, 101(suppl 1), 5266-5273. 
Bozeman, B. and Gaughan, M., 2007. Impacts of grants and contracts on academic researchers' interactions with industry. Research Policy 36, 694-707.

Bruneel, J., D'Este, P. and Salter, A., 2010. Investigating the factors that diminish the barriers to university-industry collaboration. Research Policy 39, 858-868.

Cao, Q., Gedajlovic, E. and Zhang, H., 2009. Unpacking Organizational Ambidexterity: Dimensions, Contingencies, and Synergistic Effects. Organization Science 20(4), 781-796.

Cartalos, O., Rozakis, S. and Tsiouki, D., 2016. A method to assess and support exploitation projects of university researchers. The Journal of Technology Transfer, 1-21.

Chapple, W., Lockett, A., Siegel, D.S. and Wright, M., 2005. Assessing the relative performance of university technology transfer offices in the UK: Parametric and non-parametric evidence. Research Policy 34(3), 369-434.

Chang, Y.C., Yang, P.Y., and Chen, M.H., 2009. The determinants of academic research commercial performance: Towards an organizational ambidexterity perspective. Research Policy 38, 936-946.

Chang, Y.C., Yang, P.Y., Martin, B.R. and Chi, H.R., 2016. Entrepreneurial universities and research ambidexterity: a multilevel analysis. Technovation 54, 7-21.

Coombs, R. and Hull, R., 1998. Knowledge management practices' and path-dependency in innovation. Research policy, 27(3), 237-253.

Crespi, G., D'Este, P., Fontana, R. and Geuna, A., 2011. The impact of academic patenting on university research and its transfer. Research Policy 40, 55-68.

Curi, C., Daraio, C. and Llerena, P., 2012. University technology transfer: How (in)efficient are French universities. Cambridge Journal of Economics 36, 629-654.

Danneels, E., 2011. Trying to become a different type of company: Dynamic capability at Smith Corona. Strategic Management Journal, 32(1), 1-31.

Dasgupta, P. and David, P.A., 1994, Toward a new economics of science, Research Policy 23(5), 487521.

D'Este, P. and Patel, P., 2007. University-industry linkages in the UK: What are the factors underlying the variety of interactions with industry? Research Policy 36, 1295-1313.

D'Este, P. and Perkmann, M., 2011. Why do academics engage with industry? The entrepreneurial university and individual motivations. The Journal of Technology Transfer 36, 316-339.

Deiaco, E., Holmén, M. and McKelvey, M., 2009. What does it mean conceptually that universities compete? In McKelvey, M. and Holmén, M. (Eds.), Learning to Compete in European Universities, Cheltenham: Edward Elgar, 300-328. 
Duncan, R. B. (1976). The ambidextrous organization: designing dual structures for innovation. In Kilmann, R. H., Louis, P. R. and Slevin, D. P. (Eds), The Management of Organization Design. New York: Elsevier North-Holland, 1, 167-88.

Dutrénit, G., De Fuentes, C. and Torres, A., 2010. Channels of interaction between public research organisations and industry and their benefits: Evidence from Mexico. Science and Public Policy 37(7), 513-526.

Etzkowitz, H., Webster, A., Gebhardt, C. and Terra, B.R.C., 2000. The future of the university and the university of the future: evolution of ivory tower to entrepreneurial paradigm. Research Policy 29, $313-$ 330.

Florida, R. and Cohen, W.M., 1999. Engine or infrastructure? The university's role in economic development. In: Branscomb, L.M., Kodama, F., Florida, R. (Eds.), Industrializing Knowledge: University-Industry Linkages in Japan and the United States. London, MIT Press, 589-610.

Geuna, A. and Nesta, L.J.J., 2006. University patenting and its effects on academic research: The emerging European evidence, Research Policy 35(6), 790-807.

Gibson, C.B. and Birkinshaw, J., 2004. The antecedents, consequences, and mediating role of organizational ambidexterity. Academy of management Journal, 47(2), 209-226.

Gulbrandsen, M. and Smeby, J.C., 2005. Industry funding and university professors' research performance, Research Policy 34, 932-950.

Haeussler, C., Colyvas, J.A. (2011). Breaking the Ivory Tower: Academic entrepreneurship in the life sciences in UK and Germany. Research Policy 40, 41-54.

Han, M. and Celly, N., 2008. Strategic ambidexterity and performance in international new ventures. Canadian Journal of Administrative Sciences/Revue Canadienne des Sciences de l'Administration, $25(4), .335-349$.

Hane, G., 1999. Comparing university-industry linkages in the United States and Japan. In: Branscomb, L.M., Kodama, F., Florida, R. (Eds.), Industrializing Knowledge: University-Industry Linkages in Japan and the United States. London, MIT Press, 20-61.

Hendersen, R., Jaffe, A.B. and Trajtenberg, M., 1998. Universities as a source of commercial technology: A detailed analysis of university patenting, 1965-1988. Review of Economics and Statistics 80(1), 119-127.

Hewitt-Dundas, N., 2012. Research intensity and knowledge transfer activity in UK universities. Research Policy, 4, 262-275.

House, C. and Price, R., 2009. The HP phenomenon: Innovation and business transformation. Stanford University Press. 
Howell, K.E. and Annansingh, F., 2013. Knowledge generation and sharing in UK universities: A tale of two cultures. International Journal of Information Management 33(1), 32-39.

Hughes, A. and Kitson, M., 2012. Pathways to impact and the strategic role of universities: New evidence on the breadth and depth of university knowledge exchange in the UK and the factors constraining its development. Cambridge Journal of Economics 36(3), 723-750.

Imai, K., Keele, L. and Yamamoto, T., 2010. Identification, inference and sensitivity analysis for causal mediation effects. Statistical Science 25(1), 51-71.

Kitagawa, F., Sanchez-Barrioluengo, M. and Uyarra, E., 2016. Third mission as institutional strategies: Between isomorphic forces and heterogeneous pathways. Science and Public Policy, 1-15.

Landry, R., Amara, N. and Ouimet, M., 2007. Determinants of knowledge transfer: evidence from Canadian university researchers in natural sciences and engineering. The Journal of Technology Transfer, 32(6), 561-592.

Lee, Y.S., 2000. The sustainability of university-industry research collaboration: An empirical assessment. The Journal of Technology Transfer 25, 111-133.

Lee, S., Bozeman, B., 2005. The impact of research collaborations on scientific productivity. Social Studies of Science 35(5), 673-702.

Levin, D.Z. and Cross, R., 2004. The strength of weak ties you can trust: The mediating role of trust in effective knowledge transfer. Management Science 50(11), 1477-1490.

Lin, Z., Yang, H. and Demirkan, I., 2007. The performance consequences of ambidexterity in strategic alliance formations: Empirical investigation and computational theorizing. Management science, 53(10), 1645-1658.

Lockett, A., Wright, M., Wild, A. (2015). The institutionalization of third stream activities in UK Higher Education: The role of discourse and metrics. British Journal of Management 26, 78-92.

Lubatkin, M.H., Simsek, Z., Ling, Y. and Veiga, J.F., 2006. Ambidexterity and performance in smallto medium-sized firms: The pivotal role of top management team behavioral integration. Journal of management, 32(5), 646-672.

Macpherson, A. and Ziolkowsky, M., 2005. The role of university-based industrial extension services in the business performance of small manufacturing firms: Case study evidence from Western New York. Entrepreneurship and Regional Development 17(6), 431-447.

Markides, C., 2007. In search of ambidextrous professors. Academy of Management Journal, 50, 762768.

Martin, B.R., 2012. Are universities and university research under threat? Towards an evolutionary model of university speciation. Cambridge Journal of Economics, 36 (3), 543-565. 
Mazloumian, A., Eom, Y.H., Helbing, D., Lozano, S. and Fortunato, S., 2011. How citation boosts promote scientific paradigm shifts and nobel prizes. PloS one, 6(5), p.e18975.

Molas-Gallart, J., Salter, A., Patel, P., Scott, A., and Duran, X., 2002. Measuring Third Stream Activities. Brighton: SPRU.

Morris, Z.S., Wooding, S. and Grant, J., 2011. The answer is 17 years, what is the question: understanding time lags in translational research. Journal of the Royal Society of Medicine, 104(12), $510-520$

Mowery, D.C., Nelson, R.R., Sampat, B.N. and Ziedonis, A.A., 2001. The growth of patenting and licensing by U.S. universities: An assessment of the effects of the Bayh-Dohl Act of 1980. Research Policy 30(1), 99-119.

Mowery, D.C. and Sampat, B.N., 2005. The Bayh-Dole Act of 1980 and university-industry technology transfer: A model for other OECD governments? Journal of Technology Transfer 30(1-2), 115-127.

O'Reilly, C.A. and Tushman, M.L., 2013. Organizational ambidexterity: Past, present, and future. The Academy of Management Perspectives, 27(4), 324-338.

O’Shea, R.P., Allen, T.J., Chevalier, A., Roche, F., 2005. Entrepreneurial orientation, technology transfer and spinoff performance of US universities. Research Policy 34, 994-1009.

Phan, P.H. and Siegel, D.S., 2006. The effectiveness of university technology transfer: The lessons learnt from qualitative and quantitative research in the US and UK. Foundations and Trends in Entrepreneurship 2, 66-144.

Petersen, A.M., Fortunato, S., Pan, R.K., Kaski, K., Penner, O., Rungi, A., Riccaboni, M., Stanley, H.E. and Pammolli, F., 2014. Reputation and impact in academic careers. Proceedings of the National Academy of Sciences, 111(43), 15316-15321.

Perez, M.P. and Sánchez, A.M., 2003. The development of university spin-offs: early dynamics of technology transfer and networking. Technovation, 23(10), 823-831.

Perkmann, M. and Walsh, K., 2008. Engaging the scholar: Three types of academic consulting and their impact on universities and industry. Research Policy 37, 1884-1891.

Perkmann, M. and Walsh, K., 2009. The two faces of collaborations: impacts of university-industry relations on public research. Industrial and Corporate Change 18(6), 1033-1065.

Perkmann, M., King, Z. and Pavelin, S., 2011. Engaging excellence? Effects of faculty quality on university engagement with industry. Research Policy 40, 539-552.

Perkmann, M., Tartari, V. McKelvey, M., Autio, E., Brostrom, A., D’Este, P., Fini, R., Geuna, A., Hughes, A., Krabel, S., Kitson, M., Llerena, P., Lissoni, F., Salter, A. and Sobrero, M., 2013. Academic engagement and commercialisation: A review of the literature on university-industry relations, 
Research Policy 42, 423-442.

Powell,W.W., Koput,K., and Smith-Doerr,L., 1996. Interorganizational collaboration and the locus of innovation: networks of learning in Biotechnology. Administrative Science Quarterly 41, 116-145.

Raisch, S., Birkinshaw, J., Probst, G. and Tushman, M.L., 2009. Organizational Ambidexterity: Balancing Exploitation and Exploration for Sustained Performance. Organization Science 20(4), 685695.

Ray, A.S. and Saha, S. 2011. Patenting Public-Funded Research for Technology Transfer: A Conceptual-Empirical Synthesis of US Evidence and Lessons for India. The Journal of World Intellectual Property, 14(1), 75-101.

Reagans, R. and McEvily, B., 2003. Network structure and knowledge transfer: The effects of cohesion and range. Administrative science quarterly, 48(2), 240-267.

Rossi, F. and Rosli, A., 2013. Indicators of university-industry knowledge transfer performance and their implications for universities: evidence from the United Kingdom, Studies in Higher Education 40, 1970-91.

Rosli, A. and Rossi, F., 2016. Third mission policy goals and incentives for performance-based funding: Are they aligned? Research Evaluation, 1-15.

Roux, D.J., Rogers, K.H., Biggs, H., Ashton, P.J. and Sergeant, A. 2006. Bridging the sciencemanagement divide: moving from unidirectional knowledge transfer to knowledge interfacing and sharing. Ecology and Society 11(1), 23-43.

Salter, A.J. and Martin, B.R., 2001. The economic benefits of publicly funded basic research: a critical review. Research Policy 30, 509-532.

Sanchez-Barrioluengo, M., 2014. Articulating the 'three missions' in Spanish universities'. Research Policy, 43: 1760-73.

Santoro, M.D. and Gopalkrishnan, S., 2000. The institutionalization of knowledge transfer activities within industry-university collaborations. Journal of Engineering and Technology Management, 17(34), 299-319.

Sengupta, A. and Ray, A.S., 2017. Choice of Structure, Business Model and Portfolio: Organisational Models of Knowledge Transfer Offices in British Universities. British Journal of Management, in press.

Schartinger, D., Rammer, C., Fischer, M.M. and Fröhlich, J., 2002. Knowledge interactions between universities and industry in Austria: sectoral patterns and determinants. Research Policy 31, 303-328.

Sharifi, H., Liu, W., Ismail, H.S. (2013). Higher education system and the 'open' knowledge transfer: A view from perception of senior managers at university knowledge transfer offices. Studies in Higher Education 39(10). 
Siegel, D.S., Waldman, D. and Link, A., 2003. Assessing the impact of organizational practices on the relative productivity of university technology transfer offices: an exploratory study. Research policy, 32(1), 27-48.

Siegel, D.S. and Wright, M., 2015. Academic entrepreneurship: Time for a rethink? British Journal of Management 26(4), 582-595.

Sydow, J., Schreyögg, G., and Koch, J. (2009). Organizational path dependence: Opening the black box. Academy of Management Review, 34(4), 689-709.

Thursby, J.G. and Thursby, M.C., 2002. Who is selling the ivory tower? Sources of growth of university licensing. Management Science 48(1), 90-104.

Tushman, M.L. and O'Reilly, C.A., 1996. The ambidextrous organizations: Managing evolutionary and revolutionary change. California management review, 38(4), 8-30.

Tushman, M. and O'Reilly, C., 1997. Winning Through Innovation: A Practical Guide to Leading Organizational Change and Renewal. Cambridge, MA: Harvard Business School Press.

Tushman, M.L. and O'Reilly, C.A., 2002. Winning through innovations. Harvard Business School Press, Boston.

Valdivia, W.D., 2013. University start-ups: Critical for improving technology transfer, Brookings Paper, Centre for Technology Innovation, The Brookings Institution.

Wright, M., Clarysse, B., Lockett, A. and Knockaert, M. 2008. Mid-range universities' linkages with industry: Knowledge types and the role of the intermediary, Research Policy 37, 1205-1223.

Zahra, S.A., 2008. The virtuous cycle of discovery and creation of entrepreneurial opportunities. Strategic Entrepreneurship Journal 2(3), 243-257.

Tables

Table 1: Comparisons between Russell Group and the UK HE sector

\begin{tabular}{|l|l|l|l|l|l|l|l|}
\hline & \multicolumn{7}{|c|}{ Median Values } \\
\hline \multirow{2}{*}{$\begin{array}{l}\text { Year of } \\
\text { foundation }\end{array}$} & $\begin{array}{l}\text { Average } \\
\text { Staff Size }\end{array}$ & $\begin{array}{l}\text { Research } \\
\text { output }\end{array}$ & $\begin{array}{l}\text { Research } \\
\text { output }\end{array}$ & $\begin{array}{l}\text { Number of } \\
\text { research }\end{array}$ & $\begin{array}{l}\text { Number of } \\
\text { research }\end{array}$ & Income from \\
& $(2009-10$ & KAE & (REF & active & active & Transfer \\
& to 2011- & 2008) & 2014) & departments & departments & ('000 GBP) \\
& 12 ) & & & (RAE 2008) & (REF 2014) & (2009-10 to \\
& & & & & & & 2011-12) \\
\hline
\end{tabular}




\begin{tabular}{|l|c|c|c|c|c|c|c|}
\hline $\begin{array}{l}\text { Russell } \\
\text { Group }\end{array}$ & 1897 & 2568 & 1444.8 & 2655.4 & 38.5 & 28 & 56750.5 \\
\hline Rest & 1950 & 793 & 448.6 & 324.98 & 11 & 11 & 3631 \\
\hline
\end{tabular}

Table 2: List of endogenous, exogenous and control variables used in Models 1 and 2

\begin{tabular}{|c|c|c|}
\hline Variables & Description & Summary Statistics \\
\hline \multicolumn{3}{|l|}{ Endogenous } \\
\hline$y_{I P}(t)$ & $\begin{array}{l}\text { Average IP income (2009-10 to 2011-12) from } \\
\text { commercialization through licensing and spin out activity }\end{array}$ & $\begin{array}{l}\text { Mean: } 542.4 \\
\text { Std. Dev: } 1418.4\end{array}$ \\
\hline$y_{\text {Collab }}(t)$ & $\begin{array}{l}\text { Average collaborative research income (2009-10 to } 2011-12) \\
\text { from projects involving at least one other non-academic partner, } \\
\text { but which have public sponsorship }\end{array}$ & $\begin{array}{l}\text { Mean: } 5927.7 \\
\text { Std. Dev.: } 9837.5\end{array}$ \\
\hline$y_{\text {Contract }}(t)$ & $\begin{array}{l}\text { Average income from specific contract research projects (2009- } \\
10 \text { to 2011-12) with external partners, which are not included in } \\
\text { either of the above categories }\end{array}$ & $\begin{array}{l}\text { Mean: } 7666.4 \\
\text { Std. Dev.: } 16282.0\end{array}$ \\
\hline$y_{\text {Consult }}(t)$ & $\begin{array}{l}\text { Average income from consultancy contracts (2009-10 to 2011- } \\
\text { 12) defined as provision of expert advice to the client, but } \\
\text { without the creation of new knowledge }\end{array}$ & $\begin{array}{l}\text { Mean: } 2522.6 \\
\text { Std. Dev.: } 4073.3\end{array}$ \\
\hline$R(t)$ & Research output score computed using REF 2014 data & $\begin{array}{l}\text { Mean: } 881.9 \\
\text { Std. Dev.: } 1099.7\end{array}$ \\
\hline \multicolumn{3}{|l|}{ Exogenous } \\
\hline$R(t-1)$ & Research output score computed using RAE 2008 data & $\begin{array}{l}\text { Mean: } 751.8 \\
\text { Std. Dev.: } 681.2\end{array}$ \\
\hline Avg RC income & $\begin{array}{l}\text { Average income from Research Councils UK grants (2009-10 to } \\
\text { 2011-12) }\end{array}$ & $\begin{array}{l}\text { Mean: } 2021.4 \\
\text { Std. Dev.: } 4150.2\end{array}$ \\
\hline Avg patents granted & $\begin{array}{l}\text { Average number of patents (including individual) granted } \\
(2009-10 \text { to } 2011-12)\end{array}$ & $\begin{array}{l}\text { Mean: } 5.7 \\
\text { Std. Dev.: } 15.7\end{array}$ \\
\hline Avg licenses & $\begin{array}{l}\text { Average number of licenses during years to spin-outs and other } \\
\text { clients (2009-10 to 2011-12) }\end{array}$ & $\begin{array}{l}\text { Mean: } 42.1 \\
\text { Std. Dev.: } 125.3\end{array}$ \\
\hline $\begin{array}{l}\text { Cumulative patent } \\
\text { portfolio }\end{array}$ & Total number of patents held in year 2011-12 & $\begin{array}{l}\text { Mean: } 120.0 \\
\text { Std. Dev.: } 305.1\end{array}$ \\
\hline \multicolumn{3}{|l|}{ Control } \\
\hline$y_{I P}(t-1)$ & $\begin{array}{l}\text { Average IP income in previous years }(2005-06,2006-07) \text {, } \\
\text { defined as above }\end{array}$ & $\begin{array}{l}\text { Mean: } 359.52 \\
\text { Std. Dev.: } 846.71\end{array}$ \\
\hline$y_{\text {Collab }}(t-1)$ & $\begin{array}{l}\text { Average collaborative research income in previous years }(2005- \\
06,2006-07) \text {, defined as above }\end{array}$ & $\begin{array}{l}\text { Mean: } 4587.67 \\
\text { Std. Dev: } 8108.34\end{array}$ \\
\hline$y_{\text {Contract }}(t-1)$ & $\begin{array}{l}\text { Average contract research income in previous years (2005-06, } \\
2006-07) \text {, defined as above }\end{array}$ & $\begin{array}{l}\text { Mean: } 5342.97 \\
\text { Std. Dev.: } 9964.56\end{array}$ \\
\hline$y_{\text {Consult }}(t-1)$ & $\begin{array}{l}\text { Average consultancy income in previous years }(2005-06,2006- \\
07) \text {, defined as above }\end{array}$ & $\begin{array}{l}\text { Mean: } 30.16 \\
\text { Std. Dev.: } 53.97\end{array}$ \\
\hline Avg Staff & Average size of full time academic faculty (2009-10 to 2011-12) & $\begin{array}{l}\text { Mean: } 1247.7 \\
\text { Std. Dev.: } 1185.7\end{array}$ \\
\hline Age & The year of foundation of the university & $\begin{array}{l}\text { Mean: } 1894.4 \\
\text { Std. Dev: } 133.9\end{array}$ \\
\hline
\end{tabular}




\begin{tabular}{|l|l|l|}
\hline Russell & $\begin{array}{l}\text { A dummy variable, equals 1 if the university belongs to the } \\
\text { Russell Group and zero otherwise }\end{array}$ & Sum: 24 \\
\hline Avg CPD income & $\begin{array}{l}\text { Average income from Continued Professional Development and } \\
\text { Continued Education programmes (2009-10 to 2011-12) }\end{array}$ & $\begin{array}{l}\text { Mean: 4167.5 } \\
\text { Std. Dev.: 5204.8 }\end{array}$ \\
\hline $\begin{array}{l}\text { Avg Facilities } \\
\text { income }\end{array}$ & $\begin{array}{l}\text { Average income from commercial use of facilities and } \\
\text { equipment of the university (2009-10 to 2011-12) }\end{array}$ & $\begin{array}{l}\text { Mean: 921.1 } \\
\text { Std. Dev.: 1656.5 }\end{array}$ \\
\hline
\end{tabular}

Table 3: Specific dependant variables, covariates and controls used in Models 1 and 2

\begin{tabular}{|c|c|c|}
\hline Model & Dependent Variables & Covariates and Controls \\
\hline \multirow[t]{14}{*}{ (1) } & $\log \left(y_{I P}(t)\right)$ & $R(t-1)$ \\
\hline & $\log \left(y_{\text {Contract }}(t)\right)$ & Average RC Income \\
\hline & $\log \left(y_{\text {Collab }}(t)\right)$ & Average patents granted \\
\hline & $\log \left(y_{\text {Consult }}(t)\right)$ & Cumulative Patent Portfolio \\
\hline & & Average licenses \\
\hline & & Avg Staff \\
\hline & & Age \\
\hline & & Avg CPD income \\
\hline & & Avg facilities income \\
\hline & & Russell \\
\hline & & $y_{I P}(t-1)$ \\
\hline & & $y_{\text {Collab }}(t-1)$ \\
\hline & & $y_{\text {Contract }}(t-1)$ \\
\hline & & $y_{\text {Consult }}(t-1)$ \\
\hline \multirow[t]{10}{*}{ (2) } & $\log R(t)$ & $R(t-1)$ \\
\hline & & $y_{I P}(t)$ \\
\hline & & $y_{\text {Contract }}(t)$ \\
\hline & & $y_{\text {Collab }}(t)$ \\
\hline & & $y_{\text {Consult }}(t)$ \\
\hline & & Russell \\
\hline & & Avg Staff \\
\hline & & Avg CPD income \\
\hline & & Avg facilities income \\
\hline & & Age \\
\hline
\end{tabular}


Table 4: Pairwise Pearson correlation coefficients for all (continuous) variables. Italicized values indicate non-significant coefficients ( $\mathrm{p}>0.05$ ) and bold indicates a relatively high correlation coefficient $(>0.7)$.

\begin{tabular}{|c|c|c|c|c|c|c|c|c|c|c|c|c|c|c|c|c|c|c|}
\hline & 1 & 2 & 3 & 4 & 5 & 6 & 7 & 8 & 9 & 10 & 11 & 12 & 13 & 14 & 15 & 16 & 17 & 18 \\
\hline 1. $R(t-1)$ & 1.00 & & & & & & & & & & & & & & & & & \\
\hline 2. Avg Staff & 0.61 & 1.00 & & & & & & & & & & & & & & & & \\
\hline 3. Cumulative patents & 0.51 & 0.65 & 1.00 & & & & & & & & & & & & & & & \\
\hline 4. RC Income & 0.43 & 0.53 & 0.51 & 1.00 & & & & & & & & & & & & & & \\
\hline 5. Avg Licenses & 0.26 & 0.67 & 0.33 & 0.30 & 1.00 & & & & & & & & & & & & & \\
\hline 6. Avg patents granted & 0.45 & 0.61 & 0.86 & 0.35 & 0.28 & 1.00 & & & & & & & & & & & & \\
\hline 7. Age & -0.35 & -0.34 & -0.59 & -0.44 & -0.24 & -0.60 & 1.00 & & & & & & & & & & & \\
\hline 8. Avg CPD income & 0.31 & 0.56 & 0.36 & 0.39 & 0.46 & 0.39 & -0.25 & 1.00 & & & & & & & & & & \\
\hline 9. Avg Facilities income & 0.31 & 0.41 & 0.37 & 0.39 & 0.12 & 0.43 & -0.28 & 0.18 & 1.00 & & & & & & & & & \\
\hline 10. $y_{I P}(t)$ & 0.42 & 0.67 & 0.82 & 0.59 & 0.57 & 0.69 & -0.59 & 0.45 & 0.24 & 1.00 & & & & & & & & \\
\hline 11. $y_{\text {Collab }}(t)$ & 0.57 & 0.65 & 0.58 & 0.83 & 0.33 & 0.44 & -0.40 & 0.33 & 0.39 & 0.61 & 1.00 & & & & & & & \\
\hline 12. $y_{\text {Contract }}(t)$ & 0.58 & 0.68 & 0.84 & 0.46 & 0.22 & 0.80 & -0.40 & 0.32 & 0.49 & 0.58 & 0.58 & 1.00 & & & & & & \\
\hline 13. $y_{\text {Consult }}(t)$ & 0.42 & 0.45 & 0.31 & 0.31 & 0.33 & 0.28 & -0.19 & 0.24 & 0.27 & 0.30 & 0.52 & 0.32 & 1.00 & & & & & \\
\hline 14. $y_{I P}(t-1)$ & 0.33 & 0.64 & 0.58 & 0.40 & 0.38 & 0.62 & -0.43 & 0.42 & 0.23 & 0.64 & 0.47 & 0.55 & 0.38 & 1.00 & & & & \\
\hline 15. $y_{\text {Collab }}(t-1)$ & 0.50 & 0.53 & 0.52 & 0.71 & 0.27 & 0.43 & -0.42 & 0.29 & 0.35 & 0.50 & 0.82 & 0.46 & 0.45 & 0.38 & 1.00 & & & \\
\hline 16. $y_{\text {Contract }}(t-1)$ & 0.62 & 0.67 & 0.78 & 0.45 & 0.26 & 0.69 & -0.36 & 0.32 & 0.50 & 0.55 & 0.65 & 0.94 & 0.38 & 0.50 & 0.45 & 1.00 & & \\
\hline 17. $y_{\text {Consult }}(t-1)$ & 0.02 & 0.19 & 0.15 & 0.09 & -0.02 & 0.16 & -0.01 & 0.04 & 0.23 & 0.13 & 0.12 & 0.20 & 0.09 & 0.09 & 0.08 & 0.18 & 1.00 & \\
\hline 18. $R(t)$ & 0.69 & 0.80 & 0.76 & 0.64 & 0.31 & 0.74 & -0.50 & 0.42 & 0.50 & 0.67 & 0.74 & 0.83 & 0.50 & 0.63 & 0.63 & 0.78 & 0.21 & 1.00 \\
\hline
\end{tabular}


Table 5: Regression Coefficients and Standard Errors for Model 1. (a) IP income (b) Contract income (c) Collaborative income (d) Consulting income (***: p < 0.01, **: p < $0.05 ; *: \mathrm{p}<0.1)$

\begin{tabular}{|c|c|c|c|c|c|c|c|c|}
\hline \multirow[b]{2}{*}{$\beta_{0}^{C}$} & \multicolumn{2}{|c|}{ (1a) IP } & \multicolumn{2}{|c|}{ (1b) Contract } & \multicolumn{2}{|c|}{ (1c) Collaborative } & \multicolumn{2}{|c|}{ (1d) Consulting } \\
\hline & $\begin{array}{l}2.2641 \mathrm{e}+00 \\
(5.9797 \mathrm{e}+00)\end{array}$ & $\begin{array}{l}9.3666 \mathrm{e}-01 \\
(6.6880 \mathrm{e}+00)\end{array}$ & $\begin{array}{l}3.3979 \mathrm{e}+00 \\
(6.4179 \mathrm{e}+00)\end{array}$ & $\begin{array}{l}1.0851 \mathrm{e}+00 \\
(6.8645 \mathrm{e}+00)\end{array}$ & $\begin{array}{l}-4.2030 \mathrm{e}+00 \\
(6.0305 \mathrm{e}+00)\end{array}$ & $\begin{array}{l}-5.2674 \mathrm{e}+00 \\
(6.5830 \mathrm{e}+00)\end{array}$ & $\begin{array}{l}5.4545 \mathrm{e}-01 \\
(5.8051 \mathrm{e}+00)\end{array}$ & $\begin{array}{l}-3.6015 \mathrm{e}-02 \\
(6.1567 \mathrm{e}+00)\end{array}$ \\
\hline$X_{i}$ & & & & & & & & \\
\hline$R(t-1)$ & $\begin{array}{l}4.2832 \mathrm{e}-03 * * * \\
(1.0243 \mathrm{e}-03)\end{array}$ & $\begin{array}{l}2.5260 \mathrm{e}-03 * * * \\
(8.1694 \mathrm{e}-04)\end{array}$ & $\begin{array}{l}5.6175 \mathrm{e}-03 * * * \\
(9.9771 \mathrm{e}-04)\end{array}$ & $\begin{array}{l}3.5694 \mathrm{e}-03 * * * \\
(7.6730 \mathrm{e}-04)\end{array}$ & $\begin{array}{l}4.3225 \mathrm{e}-03 * * * \\
(9.2058 \mathrm{e}-04)\end{array}$ & $\begin{array}{l}2.7358 \mathrm{e}-03 * * * \\
(7.2004 \mathrm{e}-04)\end{array}$ & $\begin{array}{l}2.7409 \mathrm{e}-03 * * * \\
(7.3441 \mathrm{e}-04)\end{array}$ & $\begin{array}{l}1.6968 \mathrm{e}-03 * * * \\
(5.4966 \mathrm{e}-04)\end{array}$ \\
\hline RC Income & $\begin{array}{l}6.4787 \mathrm{e}-05 \\
(7.4346 \mathrm{e}-05)\end{array}$ & $\begin{array}{l}2.2643 \mathrm{e}-05 \\
(9.0929 \mathrm{e}-05)\end{array}$ & $\begin{array}{l}1.0791 \mathrm{e}-04 \\
(6.5806 \mathrm{e}-05)\end{array}$ & $\begin{array}{l}4.1923 e-05 \\
(6.3787 e-05)\end{array}$ & $\begin{array}{l}1.9009 \mathrm{e}-04 * * * \\
(6.8920 \mathrm{e}-05)\end{array}$ & $\begin{array}{l}1.3935 \mathrm{e}-04 * * \\
(7.0061 \mathrm{e}-05)\end{array}$ & $\begin{array}{l}6.4943 \mathrm{e}-05 \\
(6.1249 \mathrm{e}-05)\end{array}$ & $\begin{array}{l}4.1168 \mathrm{e}-05 \\
(6.3038 \mathrm{e}-05)\end{array}$ \\
\hline Avg Patents granted & $\begin{array}{l}-3.7823 e-02 \\
(4.2257 e-02)\end{array}$ & $\begin{array}{l}-6.9617 \mathrm{e}-02 \\
(5.2581 \mathrm{e}-02)\end{array}$ & $\begin{array}{l}9.0540 \mathrm{e}-03 \\
(2.6965 \mathrm{e}-02)\end{array}$ & $\begin{array}{l}-2.7458 \mathrm{e}-02 \\
(3.0791 \mathrm{e}-02)\end{array}$ & $\begin{array}{l}2.3047 \mathrm{e}-02 \\
(2.5261 \mathrm{e}-02)\end{array}$ & $\begin{array}{l}-3.3345 \mathrm{e}-03 \\
(3.0859 \mathrm{e}-02)\end{array}$ & $\begin{array}{l}1.9230 \mathrm{e}-02 \\
(2.2202 \mathrm{e}-02)\end{array}$ & $\begin{array}{l}1.0377 \mathrm{e}-03 \\
(2.2447 \mathrm{e}-02)\end{array}$ \\
\hline Avg Licenses & $\begin{array}{l}-2.9079 \mathrm{e}-03 \\
(3.4000 \mathrm{e}-03)\end{array}$ & $\begin{array}{l}-3.0026 \mathrm{e}-03 \\
(3.6238 \mathrm{e}-03)\end{array}$ & $\begin{array}{l}-4.6967 \mathrm{e}-03 \\
(2.9471 \mathrm{e}-03)\end{array}$ & $\begin{array}{l}-5.0232 \mathrm{e}-03+ \\
(2.9749 \mathrm{e}-03)\end{array}$ & $\begin{array}{l}-4.0455 \mathrm{e}-03 \\
(2.7172 \mathrm{e}-03)\end{array}$ & $\begin{array}{l}-4.1434 \mathrm{e}-03 \\
(2.7108 \mathrm{e}-03)\end{array}$ & $\begin{array}{l}-1.8383 e-03 \\
(2.9468 \mathrm{e}-03)\end{array}$ & $\begin{array}{l}-1.9219 \mathrm{e}-03 \\
(2.8706 \mathrm{e}-03)\end{array}$ \\
\hline Cumulative patents & $\begin{array}{l}4.2653 \mathrm{e}-03+ \\
(2.3335 \mathrm{e}-03)\end{array}$ & $\begin{array}{l}2.0896 \mathrm{e}-03 \\
(2.7192 \mathrm{e}-03)\end{array}$ & $\begin{array}{l}1.7932 \mathrm{e}-03 \\
(1.9581 \mathrm{e}-03)\end{array}$ & $\begin{array}{l}-2.9067 \mathrm{e}-05 \\
(2.2928 \mathrm{e}-03)\end{array}$ & $\begin{array}{l}1.5941 \mathrm{e}-03 \\
(1.4934 \mathrm{e}-03)\end{array}$ & $\begin{array}{l}-3.7838 e-04 \\
(1.7025 e-03)\end{array}$ & $\begin{array}{l}2.7273 \mathrm{e}-04 \\
(1.2390 \mathrm{e}-03)\end{array}$ & $\begin{array}{l}-9.7976 \mathrm{e}-04 \\
(1.1634 \mathrm{e}-03)\end{array}$ \\
\hline$Z_{j}$ & & & & & & & & \\
\hline$y_{I P}(t-1)$ & $\begin{array}{l}2.7422 \mathrm{e}-04 \\
(5.0133 \mathrm{e}-04)\end{array}$ & $\begin{array}{l}3.9754 \mathrm{e}-04 \\
(5.1144 \mathrm{e}-04)\end{array}$ & - & - & - & - & - & - \\
\hline$y_{\text {Contract }}(t-1)$ & - & - & $\begin{array}{l}1.0655 \mathrm{e}-04 * \\
(6.0173 \mathrm{e}-05)\end{array}$ & $\begin{array}{l}5.5759 \mathrm{e}-05 \\
(5.0524 \mathrm{e}-05)\end{array}$ & - & - & - & - \\
\hline$y_{\text {Collab }}(t-1)$ & - & - & - & - & $\begin{array}{l}3.3834 \mathrm{e}-05 \\
(2.5063 \mathrm{e}-05)\end{array}$ & $\begin{array}{l}4.7234 \mathrm{e}-05 \\
(3.1308 \mathrm{e}-05)\end{array}$ & - & - \\
\hline$y_{\text {Consult }}(t-1)$ & - & - & - & - & - & - & $\begin{array}{l}-6.5956 \mathrm{e}-04 \\
(2.7766 \mathrm{e}-03)\end{array}$ & $\begin{array}{l}4.0607 \mathrm{e}-04 \\
(2.5718 \mathrm{e}-03)\end{array}$ \\
\hline Average Staff & $\begin{array}{l}2.8569 \mathrm{e}-03 * * * \\
(5.9147 \mathrm{e}-04)\end{array}$ & $\begin{array}{l}1.5656 \mathrm{e}-03 * * * \\
(5.8996 \mathrm{e}-04)\end{array}$ & $\begin{array}{l}3.1943 \mathrm{e}-03 * * * \\
(6.4888 \mathrm{e}-04)\end{array}$ & $\begin{array}{l}1.6408 \mathrm{e}-03 * * * \\
(6.0453 \mathrm{e}-04)\end{array}$ & $\begin{array}{l}2.7492 \mathrm{e}-03 * * * \\
(6.1373 \mathrm{e}-04)\end{array}$ & $\begin{array}{l}1.6243 \mathrm{e}-03 * * * \\
(5.4429 \mathrm{e}-04)\end{array}$ & $\begin{array}{l}1.9774 \mathrm{e}-03 * * * \\
(5.9104 \mathrm{e}-04)\end{array}$ & $\begin{array}{l}1.2609 \mathrm{e}-03 * * \\
(5.4191 \mathrm{e}-04)\end{array}$ \\
\hline
\end{tabular}




\begin{tabular}{|c|c|c|c|c|c|c|c|c|}
\hline Age & $\begin{array}{l}-3.3165 \mathrm{e}-03 \\
(3.0867 \mathrm{e}-03)\end{array}$ & $\begin{array}{l}-2.0108 \mathrm{e}-03 \\
(3.4716 \mathrm{e}-03)\end{array}$ & $\begin{array}{l}-1.6072 \mathrm{e}-03 \\
(3.3018 \mathrm{e}-03)\end{array}$ & $\begin{array}{l}3.2062 \mathrm{e}-04 \\
(3.5222 \mathrm{e}-03)\end{array}$ & $\begin{array}{l}2.7742 \mathrm{e}-03 \\
(3.0614 \mathrm{e}-03)\end{array}$ & $\begin{array}{l}3.8652 \mathrm{e}-03 \\
(3.3446 \mathrm{e}-03)\end{array}$ & $\begin{array}{l}1.3076 \mathrm{e}-03 \\
(2.9037 \mathrm{e}-03)\end{array}$ & $\begin{array}{l}1.9532 \mathrm{e}-03 \\
(3.0978 \mathrm{e}-03)\end{array}$ \\
\hline Avg CPD Income & $\begin{array}{l}1.8705 \mathrm{e}-04 * * * \\
(5.7839 \mathrm{e}-05)\end{array}$ & $\begin{array}{l}1.5867 \mathrm{e}-04 * * * \\
(5.9969 \mathrm{e}-05)\end{array}$ & $\begin{array}{l}1.3143 \mathrm{e}-05 \\
(1.2083 \mathrm{e}-04)\end{array}$ & $\begin{array}{l}-1.9791 \mathrm{e}-05 \\
(1.2562 \mathrm{e}-04)\end{array}$ & $\begin{array}{l}-4.1372 \mathrm{e}-05 \\
(1.1455 \mathrm{e}-04)\end{array}$ & $\begin{array}{l}-6.4372 \mathrm{e}-05 \\
(1.1721 \mathrm{e}-04)\end{array}$ & $\begin{array}{l}-3.6424 \mathrm{e}-05 \\
(1.2913 \mathrm{e}-04)\end{array}$ & $\begin{array}{l}-5.1273 \mathrm{e}-05 \\
(1.3078 \mathrm{e}-04)\end{array}$ \\
\hline $\begin{array}{l}\text { Avg Facilities } \\
\text { Income }\end{array}$ & $\begin{array}{l}4.0528 \mathrm{e}-04 * * * \\
(1.4510 \mathrm{e}-04)\end{array}$ & $\begin{array}{l}5.1066 \mathrm{e}-04 * * * \\
(1.5617 \mathrm{e}-04)\end{array}$ & $\begin{array}{l}9.7478 \mathrm{e}-05 \\
(1.0573 \mathrm{e}-04)\end{array}$ & $\begin{array}{l}2.6286 \mathrm{e}-04 * * \\
(1.1224 \mathrm{e}-04)\end{array}$ & $\begin{array}{l}1.9958 \mathrm{e}-04 * * \\
(9.5220 \mathrm{e}-05)\end{array}$ & $\begin{array}{l}2.8536 \mathrm{e}-04 * * * \\
(1.0118 \mathrm{e}-04)\end{array}$ & $\begin{array}{l}4.1493 \mathrm{e}-05 \\
(7.6470 \mathrm{e}-05)\end{array}$ & $\begin{array}{l}8.8378 \mathrm{e}-05 \\
(7.9545 \mathrm{e}-05)\end{array}$ \\
\hline Russell & $\begin{array}{l}7.3023 \mathrm{e}-01 \\
(6.6099 \mathrm{e}-01)\end{array}$ & $\begin{array}{l}3.6126 \mathrm{e}+00 * * * \\
(1.2924 \mathrm{e}+00)\end{array}$ & $\begin{array}{l}-6.8152 \mathrm{e}-01 \\
(6.5845 \mathrm{e}-01)\end{array}$ & $\begin{array}{l}3.7386 \mathrm{e}+00 * * * \\
(1.0278 \mathrm{e}+00)\end{array}$ & $\begin{array}{l}-4.7430 \mathrm{e}-01 \\
(5.3877 \mathrm{e}-01)\end{array}$ & $\begin{array}{l}2.1992 \mathrm{e}+00 * * \\
(9.8635 \mathrm{e}-01)\end{array}$ & $\begin{array}{l}4.3764 \mathrm{e}-01 \\
(5.5696 \mathrm{e}-01)\end{array}$ & $\begin{array}{l}2.0061 \mathrm{e}+00 * * \\
(8.6085 \mathrm{e}-01)\end{array}$ \\
\hline \multicolumn{9}{|l|}{ Interaction } \\
\hline $\begin{array}{l}R(t-1) * \text { Average } \\
\text { Staff }\end{array}$ & $\begin{array}{l}-1.8573 \mathrm{e}-06 * * * \\
(5.0464 \mathrm{e}-07)\end{array}$ & & $\begin{array}{l}-2.3490 \mathrm{e}-06 * * * \\
(4.9408 \mathrm{e}-07)\end{array}$ & & $\begin{array}{l}-1.6591 \mathrm{e}-06 * * * \\
(4.3575 \mathrm{e}-07)\end{array}$ & & $\begin{array}{l}-1.0749 \mathrm{e}-06 * * * \\
(3.3287 \mathrm{e}-07)\end{array}$ & \\
\hline$R(t-1) *$ Russell & & $\begin{array}{l}-2.9072 \mathrm{e}-03 * * * \\
(1.0116 \mathrm{e}-03)\end{array}$ & & $\begin{array}{l}-3.9591 \mathrm{e}-03 * * * \\
(9.2223 \mathrm{e}-04)\end{array}$ & & $\begin{array}{l}-2.6770 \mathrm{e}-03 * * * \\
(7.9844 \mathrm{e}-04)\end{array}$ & & $\begin{array}{l}-1.6319 \mathrm{e}-03 * * * \\
(5.9824 \mathrm{e}-04)\end{array}$ \\
\hline \multirow[t]{3}{*}{ Goodness of fit } & Adj. $R^{2}: 0.4246$ & Adj. $R^{2}: 0.381$ & Adj. $R^{2}: 0.4245$ & Adj. $R^{2}: 0.3501$ & Adj. $R^{2}: 0.3615$ & Adj. $R^{2}: 0.3177$ & Adj. $R^{2}: 0.2517$ & Adj. $R^{2}: 0.2133$ \\
\hline & $\begin{array}{l}\text { F statistic: } \\
8.872 \text { on } 12 \text { and } \\
116 \text { Df }\end{array}$ & $\begin{array}{l}\text { F statistic: } 7.564 \\
\text { on } 12 \text { and } 116 \\
\text { Df }\end{array}$ & $\begin{array}{l}\text { F statistic: } 8.868 \\
\text { on } 12 \text { and } 116 \\
\text { Df }\end{array}$ & $\begin{array}{l}\text { F statistic: } 6.746 \\
\text { on } 12 \text { and } 116 \\
\text { Df }\end{array}$ & $\begin{array}{l}\text { F statistic: } 7.038 \\
\text { on } 12 \text { and } 116 \\
\text { Df }\end{array}$ & $\begin{array}{l}\text { F statistic: } 5.967 \\
\text { on } 12 \text { and } 116 \\
\text { Df }\end{array}$ & $\begin{array}{l}\text { F statistic: } 4.587 \\
\text { on } 12 \text { and } 116 \\
\text { Df }\end{array}$ & $\begin{array}{l}\text { F statistic: } 4.587 \\
\text { on } 12 \text { and } 116 \\
\text { Df }\end{array}$ \\
\hline & $\begin{array}{l}\text { p-value: < } \\
6.67 \mathrm{e}-12\end{array}$ & $\begin{array}{l}\text { p-value: < } \\
3.53 \mathrm{e}-10\end{array}$ & $\begin{array}{l}\text { p-value: < } \\
7.76 \mathrm{e}-12\end{array}$ & $\begin{array}{l}\text { p-value: < } \\
4.32 \mathrm{e}-12\end{array}$ & $\begin{array}{l}\text { p-value: < } \\
1.75 \mathrm{e}-09\end{array}$ & $\begin{array}{l}\text { p-value: < } \\
5.09 \mathrm{e}-08\end{array}$ & $\begin{array}{l}\text { p-value: < } \\
4.83 \mathrm{e}-06\end{array}$ & $\begin{array}{l}\text { p-value: < } \\
5.12 \mathrm{e}-05\end{array}$ \\
\hline
\end{tabular}


Table 6: Regression coefficients and standard errors for Model 2. Partial model (a) includes only control variables, partial model (b) introduces past research, the full model (c) includes knowledge transfer (***: p < $0.01, * *$ : p < $0.05 ; *: \mathrm{p}<0.1)$

\begin{tabular}{|c|c|c|c|}
\hline & (2a) Partial model & (2b) Partial model & (2c) Full model \\
\hline$\beta_{0}$ & $\begin{array}{l}4.7838 \mathrm{e}+00 * * * \\
(1.5152 \mathrm{e}+00)\end{array}$ & $\begin{array}{l}3.6609 \mathrm{e}+00 * * * \\
(1.3943 \mathrm{e}+00)\end{array}$ & $\begin{array}{l}4.7067 \mathrm{e}+00 * * * \\
(1.2258 \mathrm{e}+00)\end{array}$ \\
\hline$R(t-1)$ & & $\begin{array}{l}6.7815 \mathrm{e}-04 * * * \\
(1.6360 \mathrm{e}-04)\end{array}$ & $\begin{array}{l}6.9472 \mathrm{e}-04 * * * \\
(1.4011 \mathrm{e}-04)\end{array}$ \\
\hline$y_{I P}(t)$ & & & $\begin{array}{l}-2.8295 \mathrm{e}-04 * * * \\
(7.9691 \mathrm{e}-05)\end{array}$ \\
\hline$y_{\text {Contract }}(t)$ & & & $\begin{array}{l}5.6464 \mathrm{e}-07 \\
(6.0439 \mathrm{e}-06)\end{array}$ \\
\hline$y_{\text {Collab }}(t)$ & & & $\begin{array}{l}2.7945 \mathrm{e}-05 * * * \\
(8.8194 \mathrm{e}-06)\end{array}$ \\
\hline$y_{\text {Consult }}(t)$ & & & $\begin{array}{l}1.6253 e-05 \\
(1.4783 e-05)\end{array}$ \\
\hline$Z_{j}^{\prime}$ & & & \\
\hline Russell & $\begin{array}{l}9.9064 \mathrm{e}-01 * * * \\
(3.1198 \mathrm{e}-01)\end{array}$ & $\begin{array}{l}5.6186 \mathrm{e}-01 * * * \\
(2.4219 \mathrm{e}-01)\end{array}$ & $\begin{array}{l}3.0721 \mathrm{e}-01 \\
(2.8049 \mathrm{e}-01)\end{array}$ \\
\hline Age & $\begin{array}{l}1.3770 \mathrm{e}-04 \\
(7.4612 \mathrm{e}-04)\end{array}$ & $\begin{array}{l}5.8192 \mathrm{e}-04 \\
(6.9149 \mathrm{e}-04)\end{array}$ & $\begin{array}{l}-3.7747 e-05 \\
(6.2378 e-04)\end{array}$ \\
\hline Avg Staff & $\begin{array}{l}5.1926 \mathrm{e}-04 * * * \\
(1.7761 \mathrm{e}-04)\end{array}$ & $\begin{array}{l}3.8259 \mathrm{e}-04 * * * \\
(1.3882 \mathrm{e}-04)\end{array}$ & $\begin{array}{l}4.5711 \mathrm{e}-04 * * * \\
(1.4383 \mathrm{e}-04)\end{array}$ \\
\hline $\begin{array}{l}\text { Avg CPD } \\
\text { income }\end{array}$ & $\begin{array}{l}1.1962 \mathrm{e}-05 \\
(1.0833 \mathrm{e}-05)\end{array}$ & $\begin{array}{l}1.4337 \mathrm{e}-05 \\
(1.1948 \mathrm{e}-05)\end{array}$ & $\begin{array}{l}2.1209 \mathrm{e}-05^{*} \\
(1.1086 \mathrm{e}-05)\end{array}$ \\
\hline $\begin{array}{l}\text { Avg Facilities } \\
\text { income }\end{array}$ & $\begin{array}{l}1.2685 \mathrm{e}-04 * * * \\
(3.9786 \mathrm{e}-05)\end{array}$ & $\begin{array}{l}1.2469 \mathrm{e}-04 * * * \\
(3.2670 \mathrm{e}-05)\end{array}$ & $\begin{array}{l}1.0327 \mathrm{e}-04 * * * \\
(2.9512 \mathrm{e}-05)\end{array}$ \\
\hline Goodness of fit & $\begin{array}{l}\text { Adj. } R^{2}: 0.5564 \\
\text { F statistic: } 33.1 \text { on } \\
5 \text { and } 123 \mathrm{Df} \\
\text { p-value: }<2.2 \mathrm{e}-16\end{array}$ & $\begin{array}{l}\text { Adj. } R^{2}: 0.6165 \\
\text { F statistic: } 35.29 \text { on } \\
6 \text { and } 122 \text { Df } \\
\text { p-value: }<2.2 \mathrm{e}-16\end{array}$ & $\begin{array}{l}\text { Adj. } R^{2}: 0.6465 \\
\text { F statistic: } 35.29 \\
\text { on } 6 \text { and } 122 \mathrm{Df} \\
\text { p-value: }<2.2 \mathrm{e}-16\end{array}$ \\
\hline
\end{tabular}


Table 7: Causal mediation analysis for (a) all universities and (b) non-Russell Group universities. Mediators considered are IP, Contract, Collaborative and Consulting incomes with $R(t-1)$ as the treatment and $R(t)$ as the outcome. $(* * *: \mathrm{p}<0.01, * *: \mathrm{p}<0.05 ; *: \mathrm{p}<0.1)$

\begin{tabular}{|c|c|c|c|c|}
\hline & IP & Contract & Collaboration & Consulting \\
\hline \multicolumn{5}{|l|}{ (a) All } \\
\hline $\begin{array}{l}\text { Average Mediation } \\
\text { Effect }\end{array}$ & $-5.52 \mathrm{e}-07 * *$ & $3.39 \mathrm{e}-09$ & $6.14 \mathrm{e}-08 * *$ & $3.78 \mathrm{e}-08 * *$ \\
\hline $\begin{array}{l}\text { Average Direct } \\
\text { Effect }\end{array}$ & $6.92 \mathrm{e}-04 * * *$ & $7.00 \mathrm{e}-04 * * *$ & $6.97 \mathrm{e}-04 * * *$ & $6.94 \mathrm{e}-04 * * *$ \\
\hline Total Effect & $6.91 \mathrm{e}-04 * * *$ & $7.00 \mathrm{e}-04 * * *$ & $6.97 \mathrm{e}-04 * * *$ & $6.94 \mathrm{e}-0 * * *$ \\
\hline \multicolumn{5}{|l|}{ (b) Non Russell only } \\
\hline $\begin{array}{l}\text { Average Mediation } \\
\text { Effect }\end{array}$ & $-2.89 e-07$ & $2.14 \mathrm{e}-07 *$ & $3.08 \mathrm{e}-08$ & $1.90 \mathrm{e}-08$ \\
\hline $\begin{array}{l}\text { Average Direct } \\
\text { Effect }\end{array}$ & $7.34 \mathrm{e}-04 * *$ & $7.55 \mathrm{e}-04 * *$ & $7.44 \mathrm{e}-04 * *$ & $7.42 \mathrm{e}-04 * *$ \\
\hline Total Effect & $7.34 \mathrm{e}-04 * *$ & $7.55 \mathrm{e}-04 * *$ & $7.44 \mathrm{e}-04 * *$ & $7.42 \mathrm{e}-04 * *$ \\
\hline
\end{tabular}

